\title{
A novel textile wastewater treatment using ligninolytic co-culture and photocatalysis with $\mathrm{TiO}_{2}$
}

\author{
Andrea Blanco-Vargas ${ }^{1}$, Christian Fernando Ramírez-Sierra ${ }^{1}$, Marcela Duarte-Castañeda ${ }^{2}$, \\ Milena Beltrán-Villarraga ${ }^{2}$, Luz Karime Medina-Córdoba ${ }^{2}$, Alex-Enrique Florido-Cuellar ${ }^{4}$, \\ Jairo Armando Cardona-Bedoya ${ }^{3}$, Claudia Campos-Pinilla ${ }^{2}$, \\ Aura Marina Pedroza-Rodríguez ${ }^{1, *}$
}

Edited by

Juan Carlos Salcedo-Reyes

(salcedo.juan@javeriana.edu.co)

1. Laboratorio de Microbiología

Ambiental y Suelos, Grupo de

Biotecnología Ambiental e Industrial.

Departamento de Microbiología.

Facultad de Ciencias.

Pontificia Universidad Javeriana.

Carrera 7 No 43-82, Bogotá, Colombia.

2. Laboratorio de Indicadores de Calidad en Aguas. Grupo de Biotecnología Ambiental e Industrial. Departamento de Microbiología. Facultad de Ciencias. Pontificia Universidad Javeriana.

Carrera 7 No 43-82, Bogotá, Colombia.

3. Grupo de Investigación en Materiales Semiconductores y Superiónicos. Departamento de Física. Facultad de Ciencias. Universidad del Tolima. Alto de Santa Helena, Ibagué, Colombia.

4. Universidad Nacional Abierta y a

Distancia UNAD. Ibagué, Tolima,

Colombia.

*apedroza@javeriana.edu.co

Received: 10-10-2017

Accepted: 26-06-2018

Published on line: 25-10-2018

Citation: Blanco-Vargas A, RamírezSierra CF, Duarte-Castañeda M, BeltránVillarraga M, Medina-Córdoba LK, Florido-Cuellar AE, Cardona-Bedoya JA, Campos-Pinilla C, Pedroza-Rodríguez

AM. A novel textile wastewater treatment using ligninolytic co-culture and photocatalysis with $\mathrm{TiO}_{2}$,

Universitas Scientiarum, 23 (3): 437-464, 2018. doi: 10.11144/Javeriana.SC23-3.antw

\begin{abstract}
Textile industries produce effluent wastewater that, if discharged, exerts a negative impact on the environment. Thus, it is necessary to design and implement novel wastewater treatment solutions. A sequential treatment consisting of ligninolytic co-culture with the fungi Pleurotus ostreatus and Phanerochaete crhysosporium (secondary treatment) coupled to $\mathrm{TiO}_{2} / \mathrm{UV}$ photocatalysis (tertiary treatment) was evaluated in the laboratory in order to discolor, detoxify, and reuse textile effluent wastewater in subsequent textile dyeing cycles. After $48 \mathrm{~h}$ of secondary treatment, up to $80 \%$ of the color in the wastewater was removed and its chemical and biochemical oxygen demands $\left(\mathrm{COD}\right.$, and $\left.\mathrm{BOD}_{5}\right)$ were abated in $92 \%$ and $76 \%$, respectively. Laccase and $\mathrm{MnP}$ activities were central to color removal and $\mathrm{COD}$ and $\mathrm{BOD}_{5}$ abatement, exhibiting activity values of 410 $\mathrm{U} \mathrm{L}^{-1}$ and $1428 \mathrm{U} \mathrm{L}^{-1}$, respectively. Subjecting wastewater samples to $12 \mathrm{~h}$ of tertiary treatment led to an $86 \%$ color removal and $73 \%$ and $86 \%$ COD and $\mathrm{BOD}_{5}$ abatement, respectively. The application of a sequential treatment for $18 \mathrm{~h}$ improved the effectiveness of the wastewater treatment, resulting in $89 \%$ of color removal, along with $81 \%$ and $89 \% \mathrm{COD}$ and $\mathrm{BOD}_{5}$ abatement, respectively. With this sequential treatment a bacterial inactivation of $55 \%$ was observed. $\mathrm{TiO}_{2}$ films were reused continuously during two consecutive treatment cycles without thermic reactivation. Removal percentages greater than $50 \%$ were attained. Acute toxicity tests performed with untreated wastewater led to a lethality level of $100 \%$ at $50 \%$ in Hydra attenuata and to a growth inhibition of $54 \%$ at $50 \%$ in Lactuca sativa. Whereas sequentially treated wastewater excreted a $13 \%$ lethality at $6.25 \%$ and an inhibition of $12 \%$ at $75 \%$ for $H$. attenuata and $L$. sativa, respectively. Finally, sequentially treated wastewater was reused on dyeing experiments in which $0.86 \mathrm{mg} \mathrm{g}^{-1}$ adsorbed dye per $\mathrm{g}$ of fabric, that is equivalent to $80 \%$ of dye adsorption.
\end{abstract}

Keywords: Ligninolytic co-culture; photocatalysis with $\mathrm{TiO}_{2}$; textile wastewater

\section{Introduction}

Textile industries release considerable volumes of water-soluble waste substances because of fabric dyeing processes. This waste consists of dyes (azoic, disperse, anthraquinone, etc.) and dye-related compounds (surfactants, 
Funding:

Banco de la República (Research Grant No. 2953) and Pontificia Universidad Javeriana, Bogotá. (Research Grant No. 4489).

Electronic supplementary material: Supp. 1.

OPEN ACCESS salts, polymers and solubilizing agents). Usually, these chemicals are discarded in the sewage, ending up in water bodies where they become a serious threat to the environment due to their chemical complexity and low biodegradability indexes $\left(\mathrm{BOD}_{5} / \mathrm{COD}<0.5\right)$. This $\mathrm{BOD}_{5} / \mathrm{COD}$ is the ratio between the biochemical oxygen demand $\left(\mathrm{BOD}_{5}\right)$ and the chemical oxygen demand $(\mathrm{COD})$ of a given waste product. Biodegradability indexes, such as $\mathrm{BOD}_{5} / \mathrm{COD}$, depend on dye type, concentration and its mixture with other compounds.

Azoic dyes comprise an important type of industrial dyes extensively used for dyeing cotton-made fabrics. Structurally, azoic dyes consist of three main components, (i) a chromophore formed by three aromatic rings linked together by an azo bond, (ii) an auxochrome which modifies the chromophore's light absorption, and (iii) a solubilizer. Azoic dyes bind covalently to cellulosic fibers and can thus withstand temperature, friction, and pH changes (Kongliang et al., 2014; Satapanajaru et al., 2010). During fabric dyeing processes, a fraction $(20 \%-30 \%)$ of the dye is not attached to the fiber and it is therefore released, producing color effluents with high $\mathrm{COD}$ and $\mathrm{BOD}_{5}$, entailing considerable amounts of solids, and having alkaline $\mathrm{pH}$ values and high conductivities (Qingxiang et al., 2009; Waghmode et al., 2011). In complying with environmental acts and regulations, textile industries have adopted different strategies to minimize the impact of dye residues. These strategies consist of implementing physical, chemical, and biological wastewater treatment protocols, based on sedimentation, coagulation, activated sludge, anaerobic reactors, and bio-filtration. However, these protocols have proved to be effective only to certain extent (Waghmode et al., 2011), and they are not sufficient to reduce color and toxicity, deriving in documented adverse effects on aquatic ecosystems (Jadhav et al., 2010; Punzi et al., 2015).

Complementary or sequential technologies can be used to improve conventional textile effluent wastewater treatments. Ligninolytic fungi and photocatalysis with $\mathrm{TiO}_{2}$ make suitable secondary and tertiary treatment options, respectively (Deveci et al., 2016). Ligninolytic fungi are more efficient than aerobic and anaerobic bacteria at removing and bio-transforming dye waste due to their oxidative enzymes with low substrate specificity (i.e. peroxidases and polyphenol-oxidases) (Morales et al., 2016; Morales et al., 2017; Rivera-Hoyos et al., 2013). This group of fungi is also capable of removing heavy metals and reducing $\mathrm{COD}$ and $\mathrm{BOD}_{5}$, thus increasing waste biodegradability ratios to values higher than 0.5 (Maalej et al., 2009; Puentes et al., 2012a; Sathian et al., 2014). However, they have certain limiting factors such as long processing periods, secondary sludge (biomass) production, and progressive fungal biomass inactivation as the system becomes saturated (Castillo et al., 2012). 
Heterogeneous photocatalysis with $\mathrm{TiO}_{2}$ represents an attractive tertiary treatment application that can enhance the effectivity of ligninolytic-based protocols (Deveci et al., 2016). This technology uses natural or artificial light to produce two main photo-chemical reactions that take place at the $\mathrm{TiO}_{2}$ surface trough UV-light irradiation: (i) photo-induced redox reactions of adsorbed compounds and (ii) hydrophilic photo-induced conversion of $\mathrm{TiO}_{2}$. Complete or incomplete dye mineralization via electromagnetic radiation $(\geq 3.2 \mathrm{eV})$ is based on electron hole pair production followed by recombination due to a charge transference (oxidation or reduction) process (Claudinei et al., 2015; Fernandez et al., 2015; Fernandez et al., 2016). Thus, a desirable sequential textile effluent wastewater treatment would use ligninolytic fungi to reduce high organic material and color, suspended solid concentrations, and facilitate photocatalyst action, coupled to a photocatalysis course that abates colored byproducts and decreases wastewater toxicity (Nogueira et al., 2015; Punzi et al., 2015).

The present study aimed at assessing a non-conventional biologic secondary textile wastewater treatment with an active ligninolytic fungal biomass coupled to a $\mathrm{TiO}_{2}$ physical-chemical tertiary treatment. To this end, ad hoc prepared $\mathrm{TiO}_{2}$ films were reused trough four consecutive cycles to study progressive loss of photocatalytic activity. Additionally, acute toxicity tests were performed before and after sequential treatment using the fresh-water polyp, Hydra attenuata, and Lactuca sativa, seeds as toxicity indicators. Finally, sequentially treated wastewater was utilized to carry out dyeing cotton fabric batch experiments in the laboratory.

\section{Materials and methods}

\section{Characterization of wastewater}

A set of physical, chemical and microbiological textile effluent wastewater parameters were evaluated before and after treatments (Table 1). All fungal biomass was removed from wastewater samples using a Thermo Scientific ${ }^{\circledR}$ Sorvall RC6 Plus centrifuge $\left(10800 \mathrm{~g}, 10 \mathrm{~min}, 4^{\circ} \mathrm{C}\right)$, and the following parameters were measured in the supernatant: discoloration percentage, calculated on color units according to Pallerla \& Chambers (1997); COD, calculated with the 5222D method (APHA, 2012); and $\mathrm{BOD}_{5}$, calculated with the 523D method (APHA, 2012). Further, conductivity and $\mathrm{pH}$ were determined using a digital sensor, and plate count agars were used to culture heterotrophic bacteria (CFU mL ${ }^{-1}$ ) (Fernandez et al., 2015). 
Table 1. Chemical, physical and microbiological variable values of textile effluent wastewater before and after sequential treatment with ligninolytic co-culture $/ \mathrm{TiO}_{2} / \mathrm{UV}$.

\begin{tabular}{|c|c|c|c|c|c|}
\hline Parameter & $\begin{array}{c}\text { Untreated } \\
\text { Wastewater }\end{array}$ & $\begin{array}{l}\text { Secondary } \\
\text { (VBLCC) } \\
\text { treatment } \\
\text { for } 6 \mathrm{~h}\end{array}$ & $\begin{array}{l}\text { Secondary } \\
\text { (VBLCC) } \\
\text { treatment } \\
\text { for } 48 \mathrm{~h}\end{array}$ & $\begin{array}{c}\text { Tertiary } \\
\left(\mathrm{TiO}_{2} / \mathrm{UV}\right) \\
\text { treatment } \\
\text { for } 12 \mathrm{~h}\end{array}$ & $\begin{array}{c}\text { Efficiency } \\
(\%) \text { at } 18 \mathrm{~h} \\
\text { of sequential } \\
\mathrm{VB}_{\mathrm{LCC} / \mathrm{TiO}_{2} / \mathrm{UV}} \\
\text { treatment }\end{array}$ \\
\hline Temperature $\left({ }^{\circ} \mathrm{C}\right)$ & 15 & 28 & 28 & 25 & - \\
\hline $\mathrm{pH}$ & $9.5 \pm 1.3$ & $7.1 \pm 0.7$ & $7.0 \pm 0.6$ & $8.0 \pm 0.5$ & $8.7 \pm 0.5$ \\
\hline $\begin{array}{l}\text { Conductivity } \\
\left(\mathrm{mS} \mathrm{cm}^{-1}\right)\end{array}$ & $5.2 \pm 0.9$ & $2.0 \pm 0.1$ & $1.9 \pm 1.2$ & $1.9 \pm 0.7$ & $1.9 \pm 0.1$ \\
\hline Unit color & $1617 \pm 120$ & $1245 \pm 23$ & $323 \pm 12$ & $174 \pm 22$ & $89 \pm 2.3$ \\
\hline $\mathrm{COD}\left(\mathrm{mg} \mathrm{L}^{-1}\right)$ & $7375 \pm 235$ & $5390 \pm 163$ & $556 \pm 56$ & $1423 \pm 117$ & $81 \pm 5.1$ \\
\hline $\mathrm{BOD}_{5}\left(\mathrm{mg} \mathrm{L}^{-1}\right)$ & $2965 \pm 95$ & $2250 \pm 101$ & $715 \pm 48$ & $320 \pm 28$ & $89 \pm 3.7$ \\
\hline $\begin{array}{l}\text { Heterotrophic } \\
\text { bacteria CFU } \mathrm{mL}^{-1}\end{array}$ & $60 \times 10^{6}$ & $90 \times 10^{9}$ & $11 \times 10^{10}$ & $41 \times 10^{4}$ & $53 \pm 1.9$ \\
\hline
\end{tabular}

Secondary treatment with ligninolytic co-culture

Fungal strains of Pleurotus ostreatus (HPB/P3) were obtained from the culture collection at Pontificia Universidad Javeriana (Bogotá, Colombia), and Phanerochaete chrysosporium (CDBB-H-298) were obtained from the culture collection of Department of Biotechnology and Bioengineering, CINVESTAV-IPN (México D.F., México). The two strains were cultured in wheat bran extract agar (WBEA) and wheat bran extract broth (WBEB) according to Morales et al. (2017). The inoculum was incubated for eight days at $120 \mathrm{rpm}$ and $28^{\circ} \mathrm{C}$. Viable Biomass was filtrated using Whatman filters No. 3, washed twice with distilled water and collected $\left(\mathrm{VB}_{\mathrm{LCC}}\right)$. Inactivated or non-living biomass $\left(\mathrm{NLB}_{\mathrm{LCC}}\right)$ was also included in the experiments. To this end, viable biomass was inactivated after autoclaving at $1 \mathrm{~atm}$ and $121^{\circ} \mathrm{C}$ for 15 min and ascertained by culturing all treated mycelia on WBEA for 7 days at $30^{\circ} \mathrm{C}$. After the incubation period, no mycelial growth was observed. 
A $14 \mathrm{~L}$ bubble column reactor (pneumatic reactor) was inoculated either

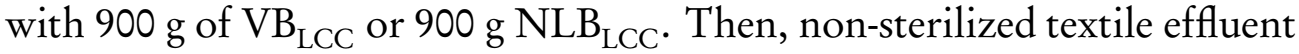
wastewater ( $10 \mathrm{~L} /$ or $71.5 \%$ of effective work volume) was added. Reactor operational conditions were set at $28{ }^{\circ} \mathrm{C}$ and air flow set at $1 \mathrm{v} . \mathrm{v} . \mathrm{m}$. This experiment was carried out in triplicate, and samples were taken at $0 \mathrm{~h}, 6 \mathrm{~h}$, 12 h, 18 h, 24 h, and 48 h. Laccase activity was determined on each sample following the methodology described by Tinoco et al. (2001), which measures Laccase activity in terms of $1 \mu \mathrm{moL}$ of oxidized ABTS per minute. Manganese peroxidase $(\mathrm{MnP})$ activity was quantified by the methodology described by Santoyo et al. (2008), MnP activity is measured in terms of the production of $1 \mu \mathrm{moL}$ of oxidized demetoxiphenol (DMP) per minute. Experiments without ligninolytic co-culture were performed to assess the activity of bacteria already present in wastewater $\left(\mathrm{WLCC}_{\text {bacteria }}\right)$. All samples were subjected to color removal and $\mathrm{COD}$ and $\mathrm{BOD}_{5}$ abatement analyses.

\section{Tertiary treatment with $\mathrm{TiO}_{2}$ films/UV}

Soda-lime glass cuts $(3.5 \times 7.0 \mathrm{~cm})$ were used as film substrates. These substrates were washed and degreased according to the methodology by Puentes et al. (2012a). $\mathrm{TiO}_{2}$ films were prepared placing each Soda-lime glass substrate on a 9 -cm diameter petri dish. A total of $20 \mathrm{~mL}$ of a $\mathrm{TiO}_{2} / \mathrm{TIP}\left(\mathrm{TiO}_{2} \mathrm{USP} /\right.$ titanium (IV) tetraisopropoxide solution was poured over each soda-lime glass substrate and allowed to dry during $5 \mathrm{~h}$ at $50{ }^{\circ} \mathrm{C}$ to form the film. Later, $\mathrm{TiO}_{2}$ films were thermally t reated at $450^{\circ} \mathrm{C}$ for $1 \mathrm{~h}$. $\mathrm{T} \mathrm{iO}$ film surface characteristics were observed using Scanning Electron Microscopy (SEM) (JEOL JSM 6490-LV electron microscope). Crystallographic characteristics of $\mathrm{TiO}_{2}$ films (Anatase and Rutile phases) were determined by X-ray diffraction as in Fernández et al. (2016).

Two cubic reactors of $20 \times 40 \times 5 \mathrm{~cm}$ (width, length, and depth), were utilized. Each one was divided into two equally-sized sections $(20 \mathrm{~cm}$ wide, $20 \mathrm{~cm}$ long, and $5 \mathrm{~cm}$ deep) to perform 2 experiments simultaneously under the same conditions (photoreactor 1 and 2). Air glass diffusers of $19 \mathrm{~cm}^{2}$, with 2-mm pores, were set inside each section. Then, UV radiation was administered using two mercury UV lamps (Philips TUV 18, $15 \mathrm{~W}$, wavelength $254 \mathrm{~nm}$ ) located parallel to each reactor, $10 \mathrm{~cm}$ away from the $\mathrm{TiO}_{2}$ films. Both reactors were placed inside a box made of galvanized metal sheets $(60 \times 50 \times 30 \mathrm{~cm})$ with an internal division to separate each reactor (Suppl. 1). Each section contained $8 \mathrm{TiO}_{2}$ films $(1000 \mathrm{mg} \mathrm{TiO}$ ) placed in contact with $400 \mathrm{~mL}$ of wastewater treated for $6 \mathrm{~h}$ with $\mathrm{VB}_{\mathrm{LCC}}$ of $P$. ostreaus and $P$. chrysosporium. UV lamps were turned on following adsorption/desorption time under dark conditions during $20 \mathrm{~min}$. A preliminary photocatalysis test was carried on samples that were previously subjected to $\mathrm{VB}_{\mathrm{LCC}}$ secondary treatment for 
$0 \mathrm{~h}, 6 \mathrm{~h}, 24 \mathrm{~h}$, and $48 \mathrm{~h}$. These experiments were performed in triplicate with $4 \mathrm{~h}$ UV irradiation. Downstream color removal percentage and COD abatement levels served to establish level analysis results on samples from this photocatalysis test, the conditions for the subsequent photocatalytic experiments.

Photocatalysis $\left(\mathrm{TiO}_{2} / \mathrm{UV}\right)$, Photolysis (UV) and adsorption removal $\left(\mathrm{TiO}_{2}\right.$ without UV light) experiments were performed in triplicate for $12 \mathrm{~h}$. Color removal, $\mathrm{COD}$ and $\mathrm{BOD}_{5}$ abatement, and microbial inactivation assays were performed on samples taken every hour along the process.

$\mathrm{TiO}_{2}$ film recycling

The number of operational cycles of each $\mathrm{TiO}_{2}$ film w as empirically determined. To this aim, a batch of eight $\mathrm{TiO}_{2}(1000 \mathrm{mg} \mathrm{TiO} 2)$ thin films was prepared per section, as previously described, and used in the treatment of wastewater previously subjected to secondary treatment for 6 hours $(1700 \pm$ $34 \mathrm{CU}$ and $2345 \pm 123 \mathrm{mg} \mathrm{L}^{-1} \mathrm{COD}$ ). The same $\mathrm{TiO}_{2}$ thin films were then reused for up to four tertiary treatment cycles. At the end of each cycle, wastewater was replaced. Wastewater from each tertiary treatment cycle was tested for discoloration and COD abatement. In addition, SEM was used to document differences between films at the beginning and end of four-cycle runs. Particular attention was payed to looking for microorganisms attached to the film's surface.

\section{Toxicity tests}

Acute toxicity tests with (L. sativa) seeds, variety Batavia Gran Lago, were carried out contrasting the toxicity of untreated wastewater, wastewater subjected to secondary treatment with ligninolytic co-culture, and wastewater subjected to secondary treatment and tertiary photocatalysis for $18 \mathrm{~h}$ $\left(\mathrm{VB}_{\mathrm{LCC}} / \mathrm{TiO}_{2} \mathrm{UV}\right.$ Sequential treatment). Additionally, $\mathrm{TiO}_{2}$ toxicity was also evaluated. Static acute toxicity tests, exposing $L$. sativa seeds for $120 \mathrm{~h}$ to the three types of wastewater were performed according to the methodology described by McInnis (1989). Toxic effects were recorded as percentage of germination inhibition. Furthermore, an acute toxicity assay was also performed with fresh-water polyps $H$. attenuata for $96 \mathrm{~h}$ following the methodology described by Trottier et al. (1997). Wastewater toxicity in $H$. attenuata was expressed as polyp mortality percentage at the highest wastewater dilution capable of driving the expected effect. 


\section{Cotton fabric dyeing tests with treated wastewater}

Distilled water, drinking water, and sequentially $\mathrm{VB}_{\mathrm{LCC}} / \mathrm{TiO}_{2} \mathrm{UV}$ treated wastewater were used in dyeing fabric experiments. This dyeing process was performed in the laboratory in quintuplicate. In each dyeing experiment, $35.8 \mathrm{mg}$ of azoic dye (Reactive Black 5) were mixed with $28 \mathrm{~mL}$ of the test waters (distilled, drinking, and $\mathrm{VB}_{\mathrm{LCC}} / \mathrm{TiO}_{2} \mathrm{UV}$ treated wastewater) in $250 \mathrm{~mL}$ flasks at $19^{\circ} \mathrm{C}$. Each solution was heated up to $90{ }^{\circ} \mathrm{C}$ and $700 \mathrm{mg}$ of sodium chloride (additive) was added. Dye and additive were mixed during $10 \mathrm{~min}$ at $100 \mathrm{rpm}$, and then a piece $(0.7 \mathrm{~g})$ of fabric was immersed in the solution. Each cotton fabric piece $(7.0 \times 7.0 \mathrm{~cm})$ was degreased and subjected to detergent and impurity elimination prior to immersion in the dyeing solution. Each tested dyeing solution, with one immersed cotton fabric, was then heated up to $90^{\circ} \mathrm{C}$ for $45 \mathrm{~min}$ and regularly stirred (each $15 \mathrm{~min}$ ) with a $30-\mathrm{cm}$ glass rod to guarantee uniform staining. Subsequently, all pieces of fabric were cooled down for $1 \mathrm{~h}$ at room temperature. The dye concentration $\left(\mathrm{mg} \mathrm{L}^{-1}\right)$ in the remaining solution was used to calculate the $q$ of adsorbed dye by cotton fabric in $\mathrm{mg} \mathrm{g}^{-1}$, see Eq. 1 .

$$
q=\frac{V(C-C o)}{x}
$$

In Eq. $1, V$ is the volume of the dyeing solution, $C$ is dye concentration $\left(\mathrm{mg} \mathrm{L}^{-1}\right), \mathrm{Co}_{\mathrm{o}}$ is the initial dye concentration $\left(\mathrm{mg} \mathrm{L}^{-1}\right)$, and $x$ is the cotton piece weight in $\mathrm{g}$. The reported $q$ is the average of the five replicates per treatment.

\section{Statistical Analysis}

Normality and variance homogeneity of untreated and treated (secondary, tertiary, and sequentially treated) data were determined with Shapiro-Wilk and Levene tests. Kruskal-Wallis nonparametric tests were performed to establish whether there were differences between treatments. Statistical significance was determined at the $95 \%(\alpha=0.05)$ level. All analyses were conducted with the Statistical Analysis System (SAS 9.0). Data from each independent experiment were presented as the means \pm standard deviation of the mean.

\section{Results}

\section{Characterization of textile wastewater}

All variables analyzed in textile effluent wastewater before and after treatments are shown in Table 1. Remarkably, untreated textile effluent wastewater variables such as color units, $\mathrm{COD}, \mathrm{BOD}_{5}$, and $\mathrm{pH}$ showed values above 
levels permitted by local environmental authorities (i.e. Resolución 3957 of Secretaría Distrital de Ambiente, Bogotá - Colombia). Moreover, the effluents had heterotrophic bacteria with morphology associated with Gram-negative and Gram-positive bacilli. Thus, tested effluents were not considered apt for discharging.

Secondary treatment with ligninolytic co-culture

Ligninolytic co-culture experiments were undertaken to assess how effectively $\mathrm{VB}_{\mathrm{LCC}}, \mathrm{NVB}_{\mathrm{LCC}}$ and $\mathrm{WLCC}_{\text {bacteria }}$ inoculates in textile effluent wastewater reduced its color and its $\mathrm{COD}$ and $\mathrm{BOD}_{5}$. Experiments were carried without $\mathrm{pH}$ control under non-sterile conditions. In terms of discoloration efficiency at $48 \mathrm{~h}$, treatments $\mathrm{VB}_{\mathrm{LCC}}, \mathrm{NVB}_{\mathrm{LCC}}$ and $\mathrm{WLCC}_{\text {bacteria }}$ resulted in color removal percentages of $80 \%, 35 \%$, and $11 \%$, respectively (Fig. 1A). Significant abatement of COD, by $92 \%$, and $\mathrm{BOD}_{5}$, by $76 \%$, were observed in the treatment with $\mathrm{VB}_{\mathrm{LCC}}$ at $48 \mathrm{~h}$, whereas percentages of $\mathrm{COD}$ and $\mathrm{BOD}_{5}$ abatement obtained after treatment with $\mathrm{NVB}_{\mathrm{LCC}}$ at $48 \mathrm{~h}$ were moderate, $41 \%$ and $25 \%$ respectively. The treatment with WLCC $_{\text {bacteria }}$ removed as low as $30 \%$ and $10 \%$ of $\mathrm{COD}$ and $\mathrm{BOD}_{5}$ under the same operational conditions (Fig. 1B and C). Statistically significant differences between treatments were observed for color removal, $\mathrm{COD}$ and $\mathrm{BOD}_{5}$ abetment, and it was established that treatment $\mathrm{VB}_{\mathrm{LCC}}$ was more efficient $(\mathrm{p}<0.0001)$ than $\mathrm{NVB}_{\mathrm{LCC}}$ and $\mathrm{WLCC}_{\text {bacteria }}$.

Ligninolytic enzymes played an important role in color removal and COD and $\mathrm{BOD}_{5}$ abatement. Laccase activity increased progressively reaching values of $452 \mathrm{U} \mathrm{L}^{-1}$ at $18 \mathrm{~h}$ of treatment. Later, laccase activity decreased to $410 \mathrm{U} \mathrm{L}^{-1}$ after $48 \mathrm{~h}$ of treatment. $\mathrm{MnP}$ activity reached a maximum activity value of $1428 \mathrm{U} \mathrm{L}^{-1}$ at $48 \mathrm{~h}$ (Fig. 2A). In the WLCC $_{\text {bacteria }}$ treatment, Laccase and $\mathrm{MnP}$ activities were not detected. Wastewater alkaline values of 8.0 were observed at the beginning of the experiments; $\mathrm{pH}$ gradually decreased to $5.5 \pm$ 0.5 , probably due to consumption of simple forms of organic carbon (residual glucose: $0.1 \mathrm{~g} \mathrm{~L}^{-1}$ at $48 \mathrm{~h}$ ) and production of citric and oxalic acids by fungi and bacteria (Fig. 2C). Bacterial growth was higher during treatment with VBLCC $\left(10 \times 10^{13} \mathrm{CFU} \mathrm{mL}{ }^{-1}\right)$ in comparison with the other two treatments, in which bacteria concentrations attained values of $10 \times 10^{8}$ and $10 \times 10^{9} \mathrm{CFU}$ $\mathrm{mL}^{-1}$ for $\mathrm{NVB}_{\mathrm{LCC}}$ and $\mathrm{WLCC}_{\text {bacteria }}$, respectively (Fig. 2B).

\section{Tertiary Treatment with $\mathrm{TiO}_{2} / \mathrm{UV}$}

Characterization of $\mathrm{TiO}_{2}$ films

Fig. 3A and fig. $\mathrm{B}$ show SEM images of $\mathrm{TiO}_{2}$ films prepared at $50^{\circ} \mathrm{C}$ and heat treated at $450^{\circ} \mathrm{C}$. Under low magnification $(5000 \mathrm{x})$, a full oxide semiconductor coating on the substrate and a film's uniform appearance was revealed. At 

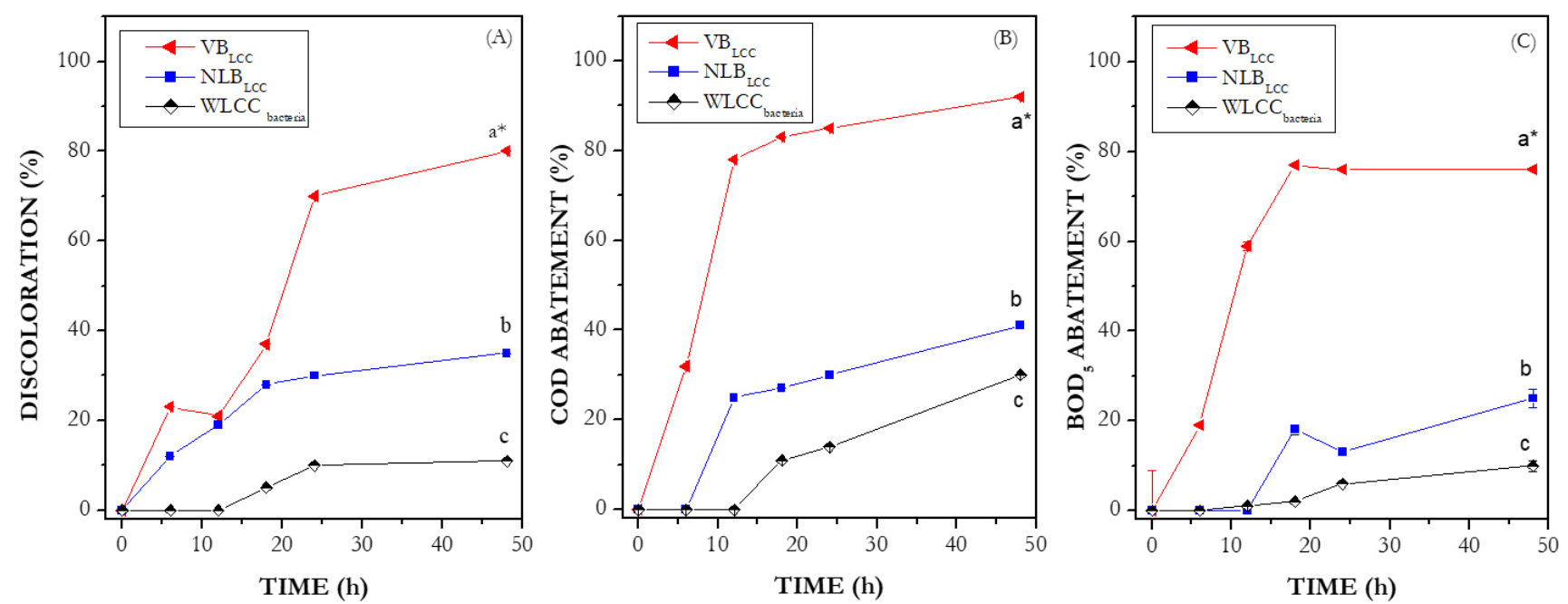

Figure 1. Effect of three ligninolytic secondary treatments on textile effluent wastewater as revealed by A) Wastewater discoloration, B) COD abatement, and C) $\mathrm{BOD}_{5}$ abatement. The three treatments were: Viable Biomass $\left(\mathrm{VB}_{\mathrm{LCC}}\right)$, Inactivated or non-living biomass $\left(\mathrm{NLB}_{\mathrm{LCC}}\right)$, and experiments without ligninolytic co-culture $\left(W_{L C C} C_{\text {bacteria }}\right)$ with operational conditions of: $1 \mathrm{~L} \mathrm{~min}^{-1}$ and $28^{\circ} \mathrm{C}$. Low case letters in the plot: $\mathrm{a}^{*}$ denotes the best treatment (i.e. $\mathrm{VB}_{\mathrm{LCC}}$ ), followed in order $\mathrm{b}$ and $\mathrm{c}$.

higher resolutions $(25000 \mathrm{x}$ and $50000 \mathrm{x})$ a rough surface, presence of different aggregate sizes, various morphologies (spherical and ovoid forms), and small cracks were revealed. These cracks are probably caused by heat treatment at $450{ }^{\circ} \mathrm{C}$. The $\mathrm{TiO}_{2}$ films had signals matched with Anatase crystalline planes (101, 103, 004, 112, 200, 105, and 211) (Fig. 3C).

\section{Photocatalytic discoloration and $\mathrm{COD}$ and $\mathrm{BOD}_{5}$ abatement}

Wastewater treated after $6 \mathrm{~h}, 24 \mathrm{~h}$, and $48 \mathrm{~h}$ by $\mathrm{VB}_{\mathrm{LCC}}$ was used for preliminary photocatalysis tests. Photocatalytic treatment for $4 \mathrm{~h}$ resulted in a $25 \%$ discoloration and in $\mathrm{COD}$ and $\mathrm{DOD}_{5}$ abatement in wastewater (Fig. 4). Based on these results, photocatalytic experiments were performed for 6 hours on wastewater previously treated by $\mathrm{VB}_{\mathrm{LCC}}$.

A maximum discoloration of $86 \%$ was obtained after $12 \mathrm{~h}$ of photocatalytic treatment of wastewater treated with $\mathrm{VB}_{\mathrm{LCC}}$. The percentages of discoloration due to photolysis and adsorption were $45 \%$ and $33 \%$, respectively (Fig. 5A). The largest COD abatement percentage $(73 \%)$ was obtained by photocatalysis 

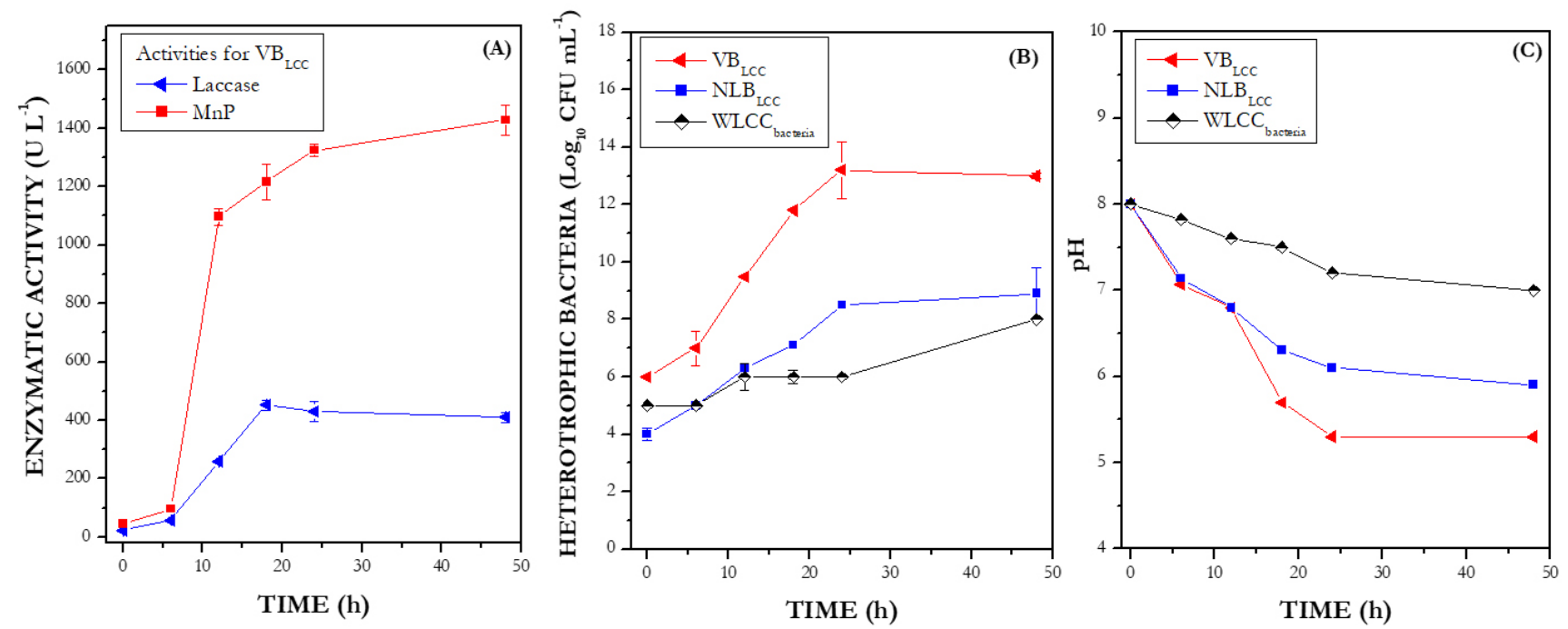

Figure 2. A) Laccase and $\mathrm{MnP}$ enzymatic profiles o bserved d uring abatement experiments only with Viable Biomass $\left(\mathrm{VB}_{\mathrm{LCC}}\right)$. B) Heterotrophic bacteria. C) pH. Operational conditions $1 \mathrm{~L} \min ^{-1}, 28^{\circ} \mathrm{C}$.

followed by photolysis with UV (25\%) and adsorption (11\%) (Fig. 5B). With respect to $\mathrm{BOD}_{5}$ abatement, the percentages obtained were $86 \%, 41 \%$, and $16 \%$ for $\mathrm{TiO}_{2} / \mathrm{UV}, \mathrm{UV}$ and $\mathrm{TiO}_{2} /$ in dark, respectively (Fig. 5C). Under the evaluated conditions, statistical differences were found between treatments ( $\mathrm{p}<0.0001$ ), establishing that discoloration, $\mathrm{COD}$ and $\mathrm{BOD}_{5}$ abatement observed after photocatalysis were higher than these obtained via photolysis and adsorption for $12 \mathrm{~h}$. Moreover, the microbial population present in wastewater $\left(9.0 \times 10^{9} \mathrm{CFU} \mathrm{mL}{ }^{-1}\right)$ was also reduced by photocatalysis. After 12 h of treatment $4.0 \times 10^{4}, 4.0 \times 10^{4}$, and $9.0 \times 10^{9} \mathrm{CFU} \mathrm{mL}^{-1}$ were found for $\mathrm{TiO}_{2} / \mathrm{UV}, \mathrm{UV}$ and adsorption respectively (data not shown).

The efficiency of the $\mathrm{VB}_{\mathrm{LCC}}-\mathrm{TiO}_{2} \mathrm{UV}$ sequential treatment (secondary treatment with $\mathrm{VB}_{\mathrm{LCC}}$ for $6 \mathrm{~h}$ and tertiary treatment with $\mathrm{TiO}_{2} \mathrm{UV}$ for $12 \mathrm{~h}$ ) was established based on the initial values of color, $\mathrm{COD}$, and $\mathrm{BOD}_{5}$ levels of untreated textile effluent wastewater. Accordingly, total removal/abatement percentages were as high as $89 \%, 81 \%$ and $89 \%$ for color, COD and BOD, respectively. Additionally, a microbial inactivation of $53 \%$ was attained (Table 1). 

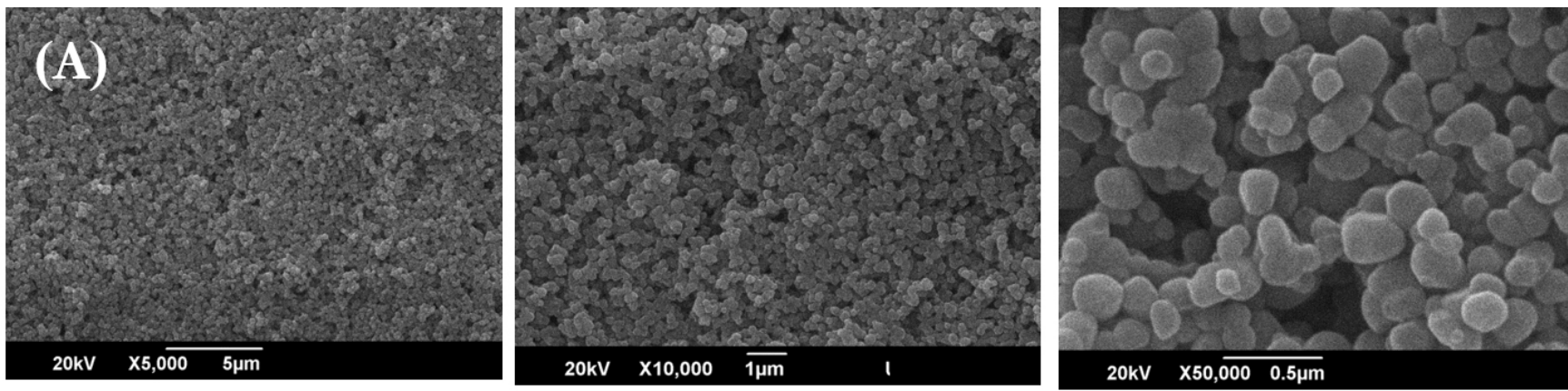

$\mathrm{TiO}_{2}$ films at $50^{\circ} \mathrm{C}$
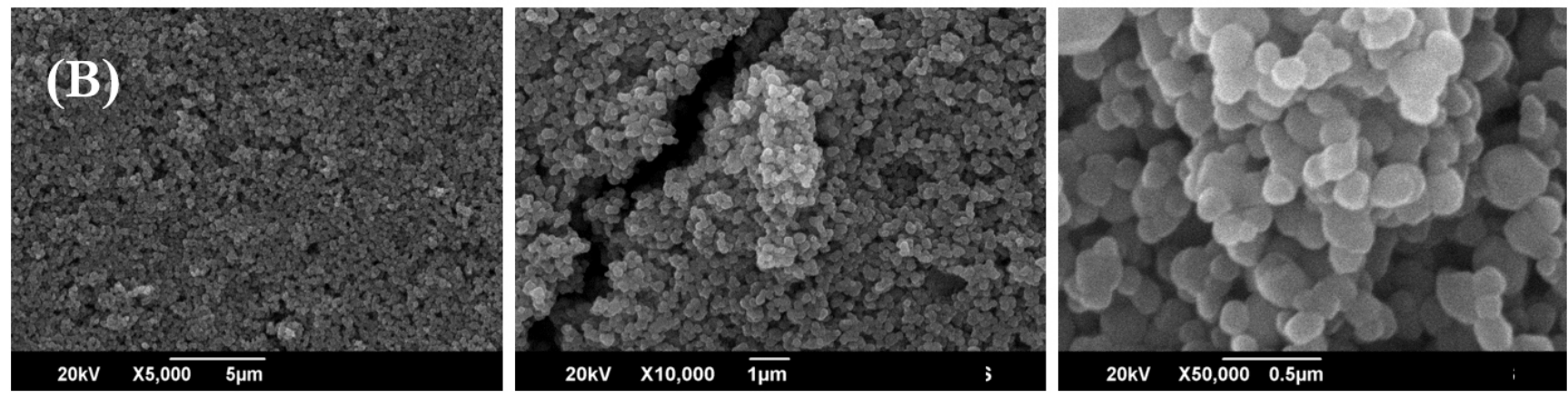

$\mathrm{TiO}_{2}$ films at $450{ }^{\circ} \mathrm{C}$

(C)

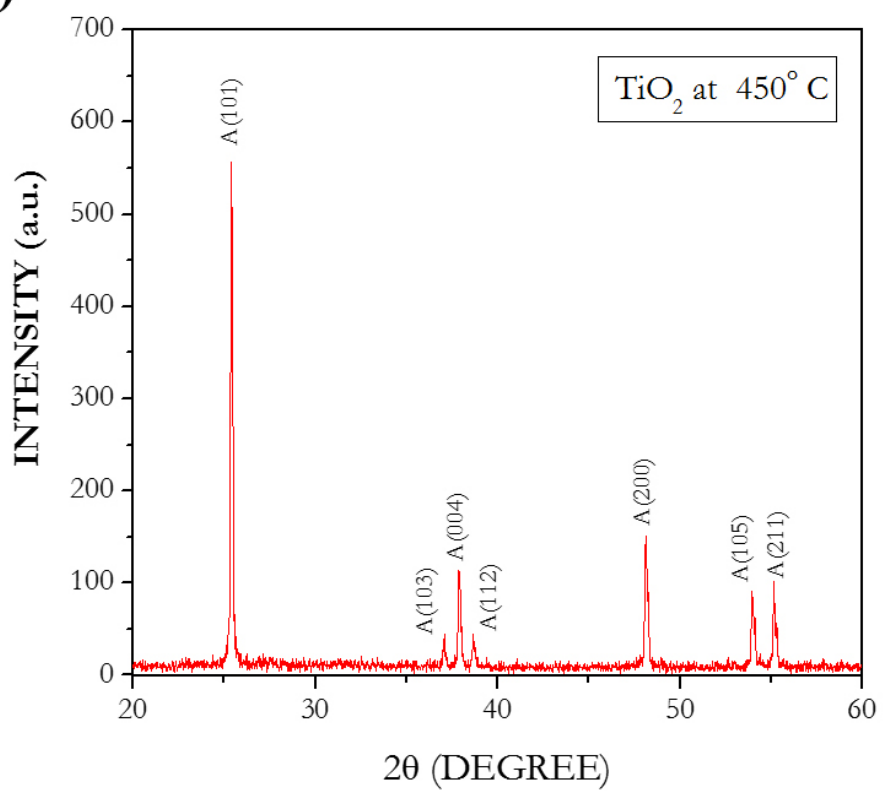

Figure 3. A) Scanning Electron Microscopy images at three amplification levels $(5000 \mathrm{X}, 10000 \mathrm{X}$, and $50000 \mathrm{X})$ of $\mathrm{TiO}_{2}$ films prepared by evaporation at $50^{\circ} \mathrm{C}$. B) Scanning Electron Microscopy views at three amplification levels $(5000 \mathrm{X}, 10000 \mathrm{X}$, and $50000 \mathrm{X}$ ) of $\mathrm{TiO}_{2}$ films calcined at $450^{\circ} \mathrm{C}$. C) X-ray diffraction spectrum for $\mathrm{TiO}_{2}$ films deposited at a substrate and annealed at $450^{\circ} \mathrm{C}$. 


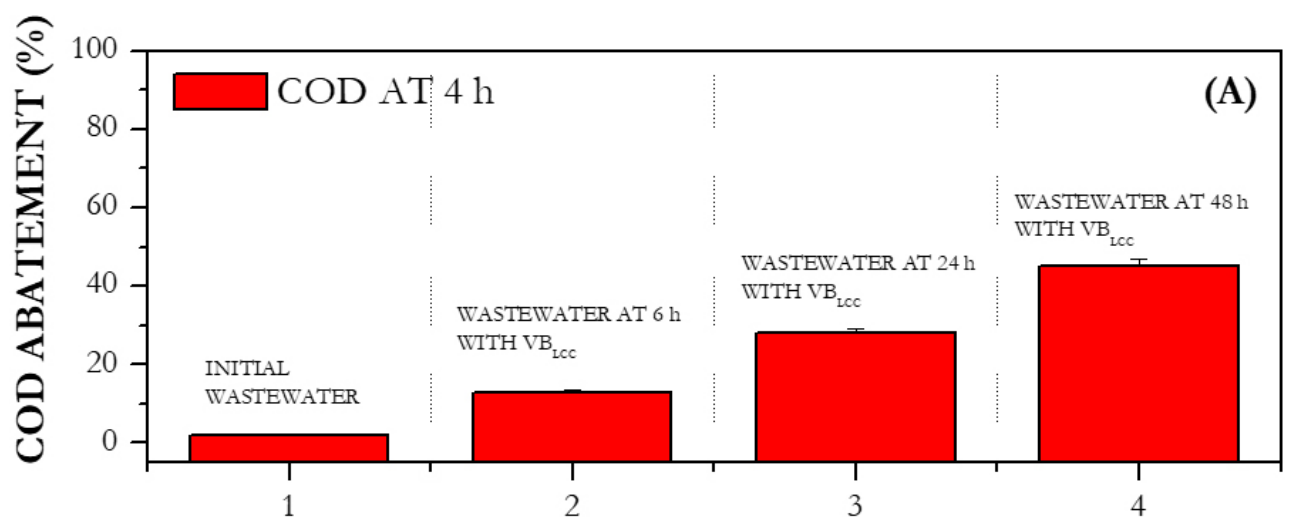

TREATMENTS

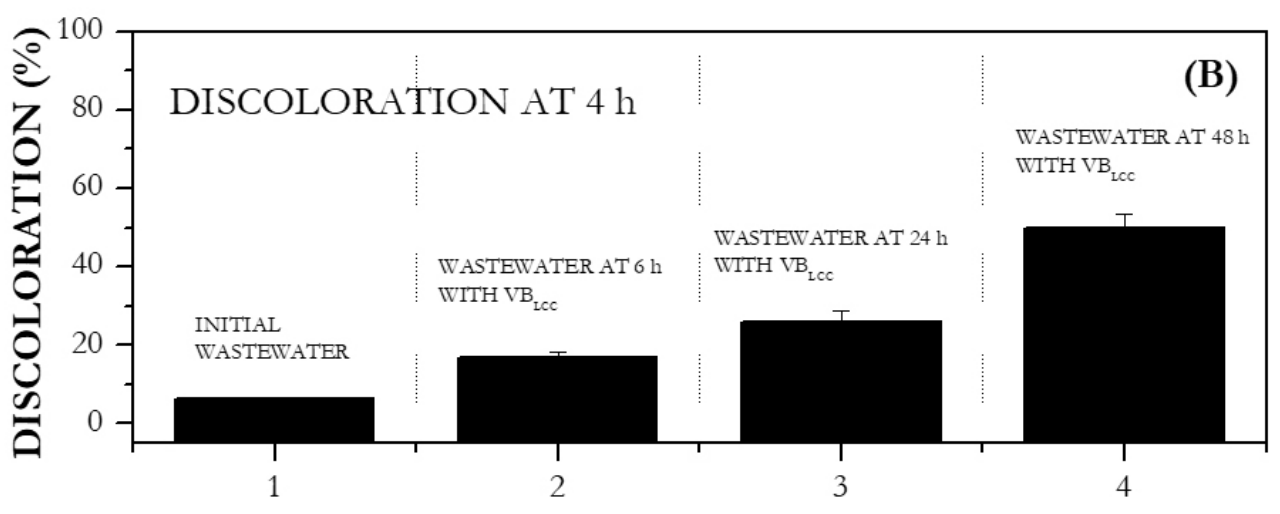

TREATMENTS

Figure 4. Effect of four secondary ligninolytic treatments on photocatalytic activity at $4 \mathrm{~h}$, as evidenced on A) COD abatement percentage and B) discoloration percentage. Ligninolytic treatments: 1. Wastewater without any secondary treatment; 2 . Wastewater at $6 \mathrm{~h}$ of secondary treatment or $\mathrm{VB}_{\mathrm{LCC}} ; 3$. water at $24 \mathrm{~h}$ of secondary treatment; and 4 . water at $48 \mathrm{~h}$ of secondary treatment or $\mathrm{VB}_{\mathrm{LCC}}$.

Recycling of $\mathrm{TiO}_{2}$ films without thermal reactivation

After $12 \mathrm{~h}$ of tertiary treatment during test cycle $1\left(\mathrm{C}_{1}\right)$ of the $\mathrm{TiO}_{2}$ films, a discoloration value of $81 \%$. was observed. Reusing the same films in subsequent cycles led to decreeing discoloration percentage of $79 \%, 33 \%$, and $32 \%$ for C2, C3 and C4, respectively (Fig. 6). Under the evaluated conditions, $\mathrm{TiO}_{2}$ films can be reused without thermal reactivation during two consecutive cycles. Concerning COD abatement and heterotroph bacteria inactivation, no statistical differences were determined between C1 (57\% COD and $54 \%$ heterotroph inactivation) and C2 (56\% COD and 51\% heterotroph inactivation). In C3 and C4, COD abatement and heterotroph bacteria inactivation were less than $40 \%$. Moreover, SEM images showed that bacterial biofilm formation increased from new (Fig. 6A) to C4 (Fig. 6B and Fig. 6C) $\mathrm{TiO}_{2}$ films. The bacterial morphology corresponds to Bacillus with terminal spores. Biofilm formation can be associated to gradual loss of photocatalytic activity, especially after C3 and C4. 

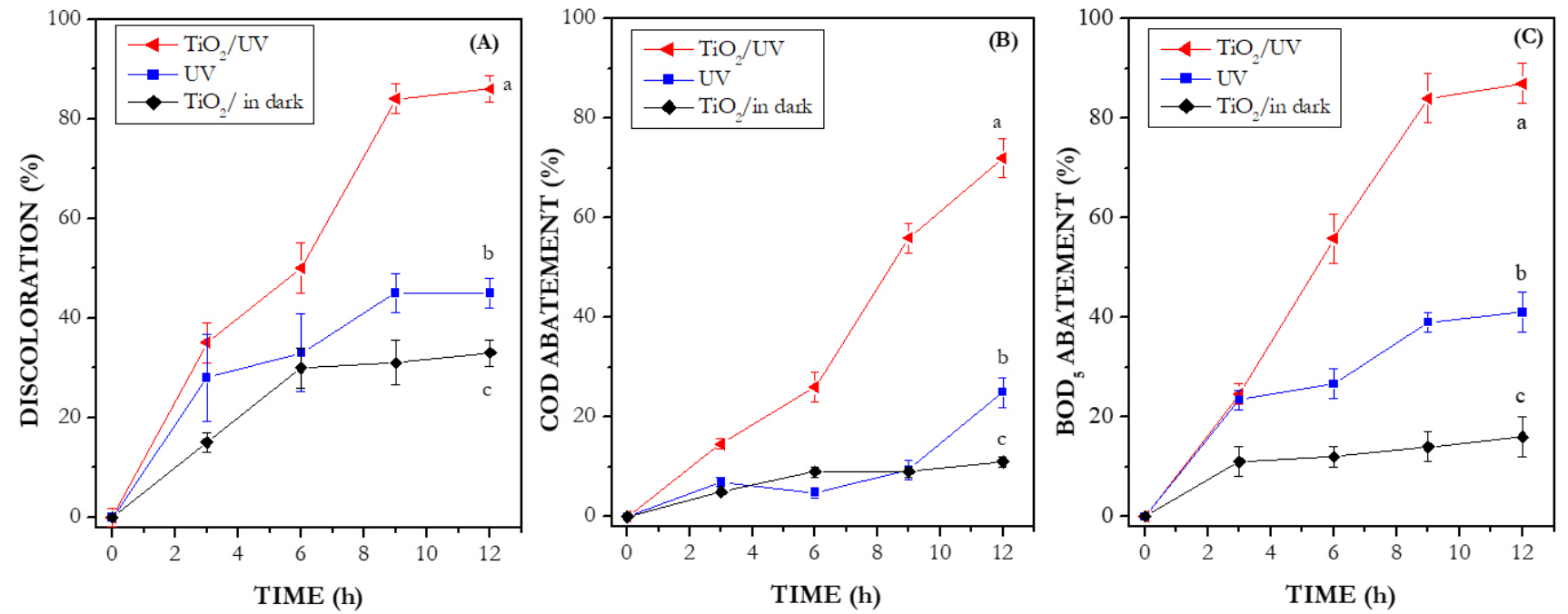

Figure 5. Discoloration a $\mathrm{BOD}_{5}$ and $\mathrm{COD}$ abatement experiments. Air $0.5 \mathrm{~L} \mathrm{~min}^{-1}, \mathrm{pH} 7.0$, temperature $25^{\circ} \mathrm{C}$.

Acute toxicity test

Wastewater without any treatment was toxic to both fresh-water polyps and letucce seeds. In the polyp, $100 \%$ at $50 \%$ lethality was observed. Moreover, acute toxicity tests with L. sativa showed $54 \%$ at $50 \%$ of inhibition. After comparing the toxicity of untreated wastewater with samples of those treated by sequential treatment $\left(\mathrm{VB}_{\mathrm{LCC}} / \mathrm{TiO}_{2} \mathrm{UV}\right)$ during $18 \mathrm{~h}$, toxicity on $H$. attenuata increase to $(13 \%$ at $6.25 \%$ ) and decreased on $L$. sativa $(12 \%$ at $75 \%)$. Additional tests were performed in order to verify $\mathrm{TiO}_{2}$ toxicity at $1 \%(w / v)$. According to data, no adverse effects of $\mathrm{TiO}_{2}$ were noticed on L. sativa ( $0 \%$ at $100 \%$ by triplicated). On the other hand, acute toxicity tests on $H$. attenuata revealed that $\mathrm{TiO}_{2}$ lethality ( $56 \%$ at $12.5 \%$ ). Most of the toxicity found on $H$. attenuata may be related to by-products formed during sequential treatment. Minor toxicity effects could be associated to $\mathrm{TiO}_{2}$.

\section{Dyeing tests using treated effluent water}

Regarding the amount $\left(\mathrm{mg} \mathrm{g}^{-1}\right)$ of adsorbed dye per gram of cotton fabric, no statistical differences were observed between wastewater treated with $\mathrm{VB}_{\mathrm{LCC}} / \mathrm{TiO}_{2} \mathrm{UV}$ at $18 \mathrm{~h}$, drinking water and distilled water $(0.86 \pm 0.02$, $0.85 \pm 0.04$, and $0.88 \pm 0.03 \mathrm{mg} \mathrm{g}^{-1}$; Fig. 7A). According to the visual assessment, the brightness and final aspect of the fabrics after dyeing were similar in all treatments. By the end of the process, $\mathrm{pH}$ values ranged between 8.0-8.5 and average conductivity was of $5.27 \mathrm{mS} \mathrm{cm}^{-1}$ (Fig. 7B and Fig. 7C). 


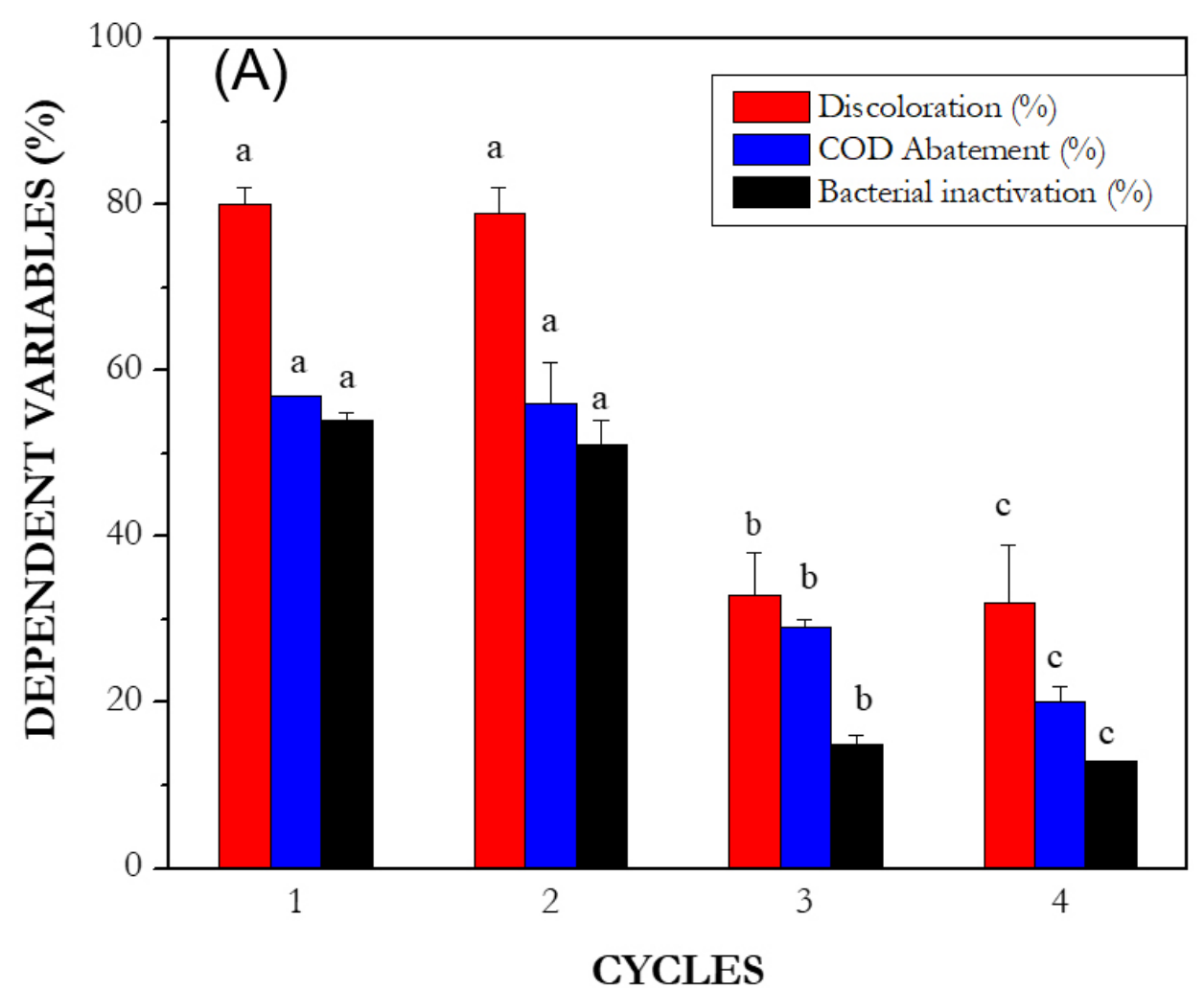

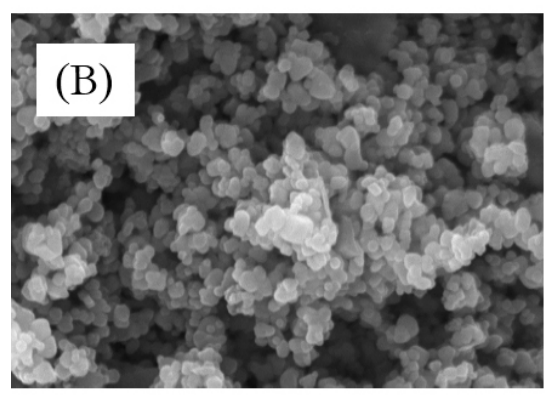

INITIAL $\mathrm{TiO}_{2}$ FILMS

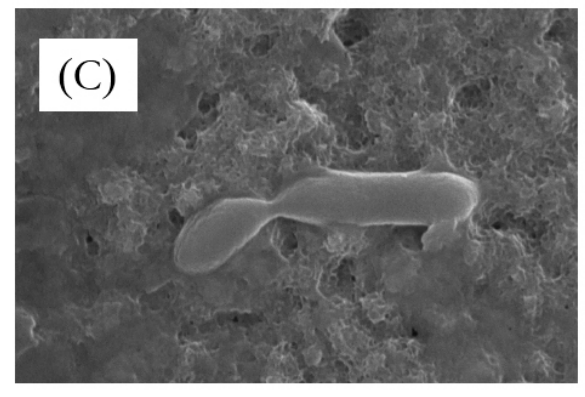

BACILLUS

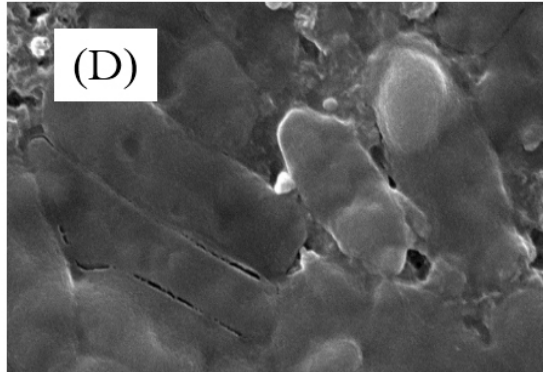

BACILLUS AND SPORE

\section{SEM AT: CYCLE 4 OF $\mathrm{TiO}_{2}$ FILMS}

Figure 6. Discoloration, COD abatement, and microbial inactivation throughout $\mathrm{TiO}_{2}$ film recycling experiments. Letters represent Tukey homogeneous subsets. a corresponds to the cycles with the best removal, followed in order by $\mathrm{b}$ and $\mathrm{c}$.

This can be related to the presence of sodium chloride acting as dyeing additive (Fig. 7B and Fig 7C). Moreover, the liquid residue obtained after dyeing tests may be treated by the sequential system and re-used in a new dyeing cycle. This will represent a zero-discharge system at the laboratory level. 

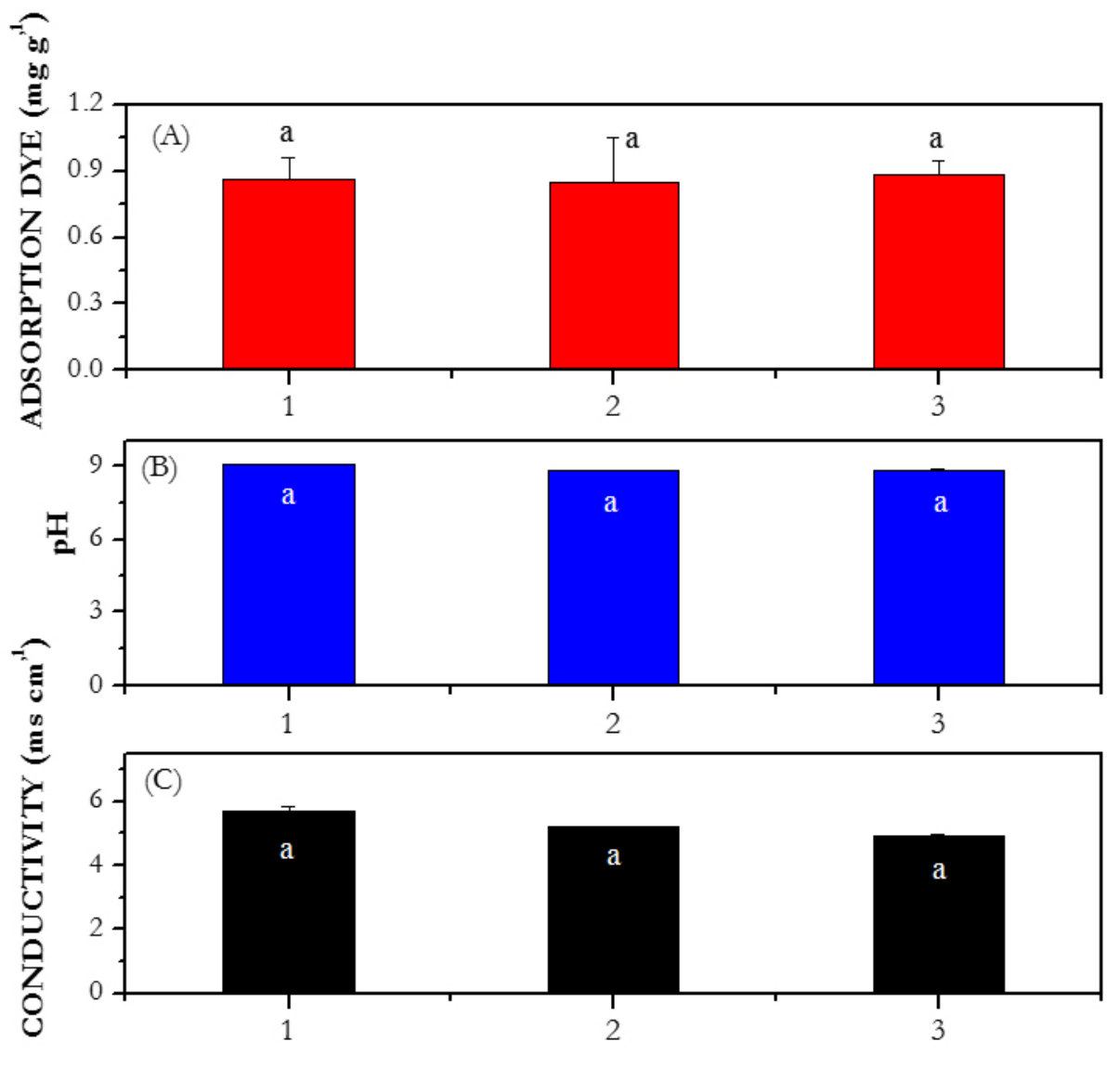

TREATMENTS
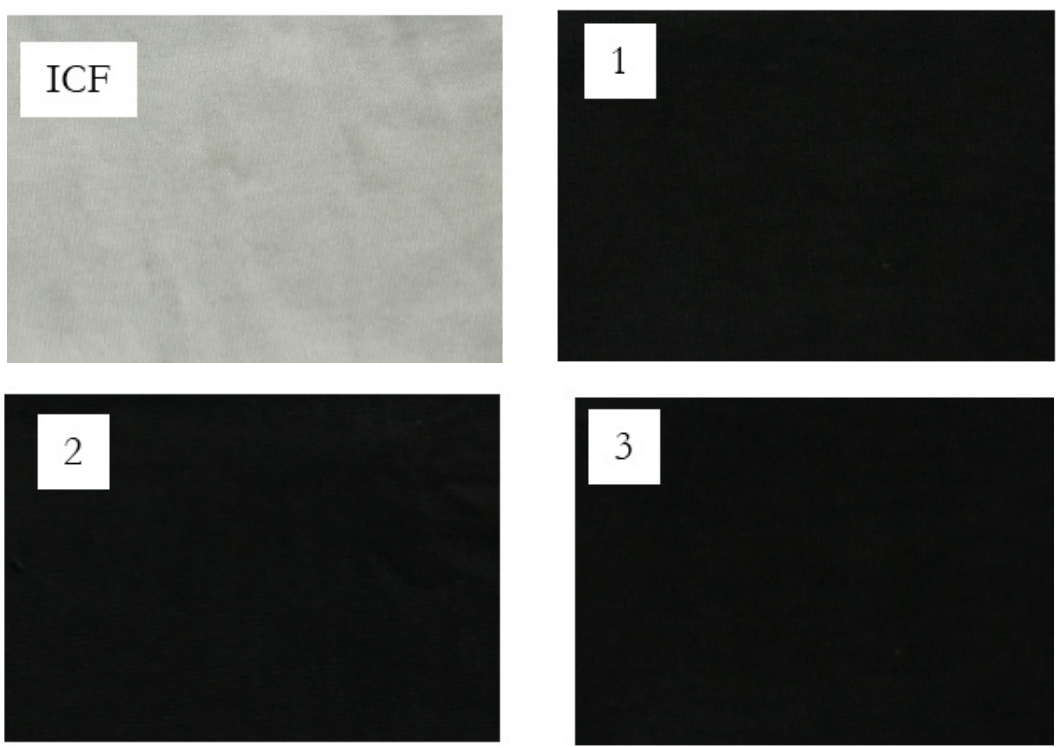

Figure 7. Reuse of sequentially treated wastewater in cotton fabric dyeing test. (ICF) Initial cotton fabric color. 1. Dyeing solution with treated wastewater with ligninolytic co-culture/TiO $/$ UV at 18 h. 2. Dyeing solution with drinking water. 3. Dyeing solution with distilled water. Letters represent Tukey homogeneous subsets. a corresponds to best dyeing treatments. 


\section{Discussion}

Secondary treatment with ligninolytic co-culture

Treating wastewater material with microorganisms can increase the efectivity of sequential or integrated oxidation (i.e. photocatalysis) procedures. This is possible because biological treatments can remove different charges of organic matter (Henao et al., 2011 and Punzi et al., 2015).

In the current work, the observed $\mathrm{COD}$ and $\mathrm{BOD}_{5}$ values were associated to the presence of five different azoic dye types in textile effluent wastewater. Hence mechanisms of textile effluent $\mathrm{w}$ a s tewater $\mathrm{d}$ is coloration a $\mathrm{l}$ s o led to abatement of $\mathrm{COD}$ and $\mathrm{BOD}_{5}$ values. Two mechanisms can relate to discoloration via $\mathrm{VB}_{\mathrm{LCC}}$. First, dyes can be absorbed into fungal walls, which possess functional groups acting as ligands, (i.e. carboxyl, amine, hydroxyl, phosphate, thiol, etc.) (Morales et al., 2017; Puentes et al., 2012b). Second, following dye adsorption, ligninolytic enzymes can generate modifications in the chemical structure of the dyes. These enzymes can cleavage azo bonds $(\mathrm{N}=\mathrm{N})$ modifying chromophore groups, and therefore changing visible spectrum adsorption. Later, byproducts may be oxidized, reduced, demethylated, and hydroxylated producing benzene or substituted quinones (Maljaei et al., 2009; Osma et al., 2010).

The fact that $\mathrm{NVB}_{\mathrm{LCC}}$ showed some adsorption capacity can be a consequence of the heat treatment (autoclaving) itself. The heat treatment to which $\mathrm{NVB}_{\text {LCC }}$ inoculates were subjected can generate a considerable number of functional groups that enhance color removal and led to the observed moderate COD and $\mathrm{BOD}_{5}$ abatement levels (Russo et al., 2010). Further, in the experiments without ligninolytic co-culture $\left(\mathrm{WLCC}_{\text {bacteria }}\right)$, the observed levels of $\mathrm{COD}, \mathrm{BOD}_{5}$ abatement and color removal were related to bacterial activity, probably as a result of enzyme activities such as peroxidases, azoreductases, riboflavin r eductases, NADH-DCIP reductase and aminopyrine $\mathrm{N}$-demethylase (Singh et al., 2015).

Positive interactions between fungi and bacteria have been previously described by Pedroza et al. (2018). These authors found that gram-positive and gram-negative bacteria, along with two white rot fungi (Pleurotus ostreatus and Trametes versicolor), can efficiently remove dyes from wastewater. Similar results were found in the present study, indicating that ligninolytic co-cultures can be used in bio reactors without specific s terile c ontrol conditions and that fungi are not inhibited by bacteria. Moreover, the presence of fungi may favor bacterial growth as evidenced by a bacterial biomass increase from $6.0 \times 10^{6}$ to $10 \times 10^{10} \mathrm{CFU} \mathrm{mL}^{-1}$. Fungal ligninolytic enzymes are likely to attack complex molecules producing simpler ones that can be transformed by bacteria (Pedroza et al., 2018; Singh et al., 2015; Fig. 2A and 2B). 
Concerning enzymatic activities, Laccase and $\mathrm{MnP}$ activity increased gradually. This may be related to an inducer effect caused by the dyes. In fact, the chemical structure of azoic dyes, which is made of aromatic rings, resembles that of phenyl propane units present in lignin. This has an enzyme enhancement effect. A possible scenario can be proposed in which the chromophore group is modified by the action of Laccase and then aromatic rings are transformed by MnP. This is drawn from findings by Morales et al. (2016) in which $P$. ostreatus laccase modified chromophore groups of Malachite Green, and then peroxidases were able attack aromatic rings.

\section{Tertiary treatment with $\mathrm{TiO}_{2} / \mathrm{UV}$}

In the present study, preliminary tests showed that high concentrations of color and elevated COD values (as seen in wastewater without treatment) affected photocatalytic degradation. This can be explained by color and organic matter loads acting as a screen blocking the passage of UV light; thus affecting electron hole pair formation and leading to deficient rates of reactive oxygen species production. The effect of pollutant concentration on photocatalytic degradation has been previously reported by Puentes et al. (2012a). These authors evidenced that at high concentrations (80 $\mathrm{mg} \mathrm{L}^{-1}$ and $100 \mathrm{mg} \mathrm{L}^{-1}$ ) of the azoic dye Reactive Black 5 (RB5), discoloration and COD abatement percents were as low as $15 \%$ and $10 \%$, respectively, at $10 \mathrm{~h}$ of treatment. Conversely, at low pollutant concentrations (10 $\mathrm{mg} \mathrm{L}^{-1}, 50 \mathrm{mg} \mathrm{L}^{-1}$ and $70 \mathrm{mg} \mathrm{L}^{-1}$ ), discoloration was as high as $80 \%$ during the sames period of time.

After analyzing tertiary treatment results, it was noted that photocatalysis $\left(\mathrm{TiO}_{2} / \mathrm{UV}\right)$ was more efficient than ultraviolet light and adsorption. The process was initiated by adsorption of residual dyes thanks to the $\mathrm{pH}$ conditions of the wastewater that facilitated residual dye transformation. This transformation is likey due to UV light interactions with the catalyst that lead to reactive oxygen species pruduction ending in dye structural modifications, namely at $\mathrm{N}=\mathrm{N}$ and $\mathrm{C}-\mathrm{N}$ b onds. Aditionally, this process would produce by-products like aromatic (phenols, amines, quinones etc), aliphatic compounds, and dissolved ions, such as $\mathrm{NO}^{-}{ }_{3}, \mathrm{~N}_{2}$ and $\mathrm{SO}_{4}{ }^{2}$ (Henao et al., 2011; Puentes et al., 2012a).

The observed limited re-usability of $\mathrm{TiO}_{2}$ films c ould b e r elated to progressive inactivation of $\mathrm{TiO}_{2}$ excreted by adsorbed by-products onto the semiconductor's oxide surface. These by-products could block available active sites and prevent photonic excitation. Another aspect that could affect $\mathrm{TiO}_{2}$ performance at each usage cycle can be associated to bacterial population size $\left(9.0 \times 10^{9} \mathrm{CFU} \mathrm{mL}{ }^{-1}\right)$. Bacteria can progressively cover $\mathrm{TiO}_{2}$ film surface creating biofilms. In addition, bacteria could behave like suspended solids 
at high concentrations blocking UV light. This assumption was confirmed by SEM of $\mathrm{TiO}_{2}$ films obtained prior and after $\mathrm{TiO}_{2}$ film usage cycle C4 (Fig. 7), in which a bacterial biofilm was observed. Previous studies have tested film reusability. Yue e et al. (2010) created a novel composite film made of $\mathrm{Cds} / \mathrm{TiO}_{2} / \mathrm{NTF}$ for methyl orange discoloration. This novel material removed $90 \%$ of color and endured five continuous usage cycles of $10 \mathrm{~h}$ each. However, in Yue e et al. (2010), a single dye at low concentration was evaluated, in contrast with the dye mixture used in our study.

Some toxic by-products could be produced after industrial wastewater treatment by combined technologies. These can sometimes be even more toxic to different organisms than the original untransformed compounds. Hence, it is important to verify water quality in terms of toxicity. Based on the current results, wastewater without any treatment was slightly toxic to $H$. attenuata and $L$. sativa, being $H$. attenuata more sensitive than $L$. sativa. This may be associated with the presence of azoic dyes, additive salts, and solubilizers which have been previously reported as toxic and potentially carcinogenic (Almeida \& Corso 2014).

Wastewater toxicity on $H$. attenuata increased by the end of the sequential treatment, probably due to the presence of by-products formed during the process and the $\mathrm{TiO}_{2}$ washed off from the films. This compounds and particulate material would be absorbed by the target organisms, causing alterations in their digestive tract and producing morphological changes (Castillo et al., 2013, Allouni 2009, Rizzo 2011). The current results agree with the observation by Henao-Jaramillo et al. (2011) that the toxicity of an RB5 (300 mg L ${ }^{-1}$ ) solution increased after being treated with Trametes versicolor and photocatalysis with $\mathrm{TiO}_{2}$.

Lettuce ( $L$. sativa) was less sensitive than $H$. attenuara, and responded more favorably to sequentially treated wastewater. L. sativa seeds were likely to be less sensitive to toxic effects due to a strong external layer made of hemicellulose and cellulose. These natural polymers tend to be hydrophobic and protect the seeds. Similar results are recorded by Puentes et al., 2012a who evaluated RB5 toxicity pre and post photocatalytic treatment. They showed that a solution of RB5 without treatment causes an inhibition percentage of $10 \%$ at $100 \%$. This result was slightly different in comparison to the one obtained in the present study $(56 \%$ at $50 \%)$. A possible reason for this difference could be the synergic toxic effect of the mixture of dyes and additives present in textile wastewater as opposed to that of a single dye.

Adsorption of RB5 takes place in 5 stages. First, the dye is adsorbed by cellulose fibers and then it diffuses in the matrix. Second, the dye is fixed to the fabric under favorable conditions of alkaline $\mathrm{pH}$, additives and temperature. 
Next, the dye attaches to the active sites of the fiber through covalent bonds (nucleophilic substitutions). The last stage is the final wash and drying; in which unabsorbed dye is washed out from the fabric, and it acquires brightness and a uniform color (Sufian et al., 2016). In the present work, just $20 \%$ of the dye was lost in the final wash out. On average, $30 \%$ dye losses could be expected in textile dye procedures, thus the results are promising and show that textile effluent wastewater recycling after treatment is possible. However, large scale studies should be performed to determine the optimal number of treated wastewater re-usage cycles. The process can help to reduce the volume of wastewater produced and is a good approach to zero discharge in the textile industry.

\section{Conclusions}

A laboratory-scale sequential system to treat textile wastewater was developed and evaluated. The present work showed that final textile effluent wastewater can be treated by subjecting it to a secondary treatment with a fungal co-culture for $6 \mathrm{~h}$, coupled to a tertiary treatment consisting of photocatalysis with $\mathrm{TiO}_{2}$ for $12 \mathrm{~h}$.

Thanks to this proposed sequential treatment, wastewater color was removed and $\mathrm{COD}$ and $\mathrm{BOD}_{5}$ abated. However, treated wastewater remained ostensibly toxic to fresh-water polyp, $H$. attenuata, and lettuce, L. sativa, seeds.

The reutilization of $\mathrm{TiO}_{2}$ films and treated wastewater was evaluated. $\mathrm{TiO}_{2}$ films $\mathrm{c}$ an $\mathrm{b}$ e r eused f or $\mathrm{t}$ wo $\mathrm{c}$ ontinuous o perational $\mathrm{c}$ ycles a nd treated wastewater can be recycled and used in cotton fabric dyeing.

\section{Acknowledgements}

Authors acknowledge Juan Camilo Pedroza Cabezas, Carlos Pedroza, and Jorge Andres Fernandez for technical support with graphical abstracts, photocatalytic reaction design and for English review of this manuscript. This work was funded by Banco de la República (Research Grant No. 2953), Pontificia Universidad Javeriana, Bogotá and Universidad de Tolima, Ibagúe, Colombia (Research Grant No. 4489).

\section{Conflict of interest}

The authors declare that no competing interests exist.

\section{Reference}

Allouni Z, Cimpan M. Agglomeration and sedimentation of $\mathrm{TiO}_{2}$ nanoparticles in cell culture medium. Colloids Surface B: Biointerfaces 68: 83-87, (2009).

doi: 10.1016/j.colsurfb.2008.09.014 
Almeida EJR, Corso CR. Comparative study of toxicity of azo dye Red MX-5B following and biodegradation a treatments with the fungi Aspergillus niger and Aspergillus terreus, Chemosphere, 112 :317322, 2014.

doi: 10.1016/j.chemosphere.2014.04.060

APHA. Standard Methods for the Examination of Water and Waste Water. 22nd Edition, American Public Health Association, American Water Works Association, Water Environment Federation. 2012

Castillo-Carvajal LC, Ortega-González K, Barragán-Huerta BE, Pedroza-Rodríguez AM. Evaluation of three immobilization supports and two nutritional conditions for reactive black 5 removal with Trametes versicolor in air bubble reactor, African Journal of Biotechnology, 11: 3310-3320, 2012

doi: $10.5897 /$ AJB11.1217

Castillo-Carvajal LC, Pedroza-Rodriguez AM, Barragan-Huerta BE. Adsorption and biological removal of Basic Green 4 dye using white-rot fungi immobilized on Agave tequilana Weber waste, Fresenius Environmental Bulletin, 22: 2324-2343, 2013

Claudinei Lima S, Batista KA, Garcia Rodriguez, Souza JR, Fernandes KF. Photodecomposition and color removal of a real sample of textile wastewater using heterogeneous photocatalysis with polypyrrole, Solar Energy, 114: 105-113, 2015.

doi: 10.1016/j.solener.2015.01.038

Deveci EÜ, Dizge N, Yatmaz HC, Berrin T. Degradation of Recalcitrant Textile Dyes by Coupling Fungal and Photocatalytic Membrane Reactors, Clean Soil Air Water, 44(10): 1345-1351, 2016. doi: 10.1002/clen.201500838

Fernández JA, Cardozo MG, Carrascal AK, Salcedo JC, Pedroza AM, Daza CE. Microbiology cell-staining wastewater treatment using $\mathrm{TiO}_{2}$ thin films, Ingeniería y Competitividad, 17(1): 35-48, 2015.

Fernández JA, Suan A, Ramírez JC, Robles J, Salcedo JC, Pedroza AM, Daza CE. Treatment of real wastewater with $\mathrm{TiO}_{2}$-films sensitized by a natural-dye obtained from Picramnia sellowii, Journal of Environmental Chemical Engineering, 4(3): 2848-2856, 2016.

doi: 10.1016/j.jece.2016.05.037 
Henao L, Fernández J, Quevedo B, Florido-Cuellar A, Pedroza AM. Removal of reactive black 5 dye by $\mathrm{T}$. versicolor immobilized on Luffa cylindrica sponge and homogeneous photocatalysis with $\mathrm{TiO}_{2}$, International Biotechnology Color Journal, 1(1): 1-19, 2011

Jadhav JP, Kalyani DC, Telke AA, Phugare SS, Govindwar SP. Evaluation of the efficacy of a bacterial consortium for the removal of color, reduction of heavy metals, and toxicity from textile dye effluent, Bioresource Technology, 101(1): 165-173, 2010.

doi: 10.1016/j.biortech.2009.08.027

Kongliang X, Aiqin G, Min L, Xiao W. Printing properties of the red reactive dyes with different number sulfonate groups on cotton fabric, Carbohydrate Polymers, 101(1): 666- 670, 2014.

doi: 10.1016/j.carbpol.2013.09.107

Maalej-Kammoun M, Zouari Mechichi H, Belbahri L, Woodward S, Mechichi T. Malachite green decolourization and detoxification by the laccase from a newly isolated strain of Trametes sp., International Biodeterioration Biodegradation, 63: 600-606, 2009.

doi: 10.1016/j.ibiod.2009.04.003

Maljaei A, Arami M, Mahmoodi NM. Decolorization and aromatic ring degradation of colored textile wastewater using indirect electrochemical oxidation method, Desalination, 249: 1074-1078, 2009.

doi: 10.1016/j.desal.2009.05.016

Mcinnis R. Short term elongation toxicity bioassay. National Water Research Institute (NWRI). Québec, Canada, 1-7, 1989.

Morales-Álvarez ED, Rivera-Hoyos CM, Chaparro-Núñez LE, Daza CE, Poutou-Piñales RA, Pedroza-Rodríguez AM. Decolorization and Detoxification of Malachite Green by Ganoderma lucidum: Key Operating Parameters and Adsorption Studies, Journal Environmental Engeneering, 143(4): 1-12, 2017

doi: 10.1061/(ASCE)EE.1943-7870.0001180

Morales-Álvarez ED, Rivera-Hoyos CM, González-Ogliastri N, Rodríguez-Vázquez R, Poutou-Piñales RA, Daza CE, PedrozaRodríguez AM. Partial removal and detoxification of Malachite Green and Crystal Violet from laboratory artificially contaminated water by Pleurotus ostreatus, Universitas Scientiarum, 21(3): 259-285, 2016.

doi: 10.11144/Javeriana.SC21-3.prad 
Nogueira V, Lopes I, Freitas AC, Rocha-Santos TAP, Gonçalves F, Duarte AC, Pereira R. Biological treatment with fungi of olive mil wastewater pre-treated by photocatalytic oxidation with nanomaterials, Ecotoxicology and Environmental Safety, 115: 234-242, 2015.

doi: 10.1016/j.ecoenv.2015.02.028

Osma JF, Toca-Herrera JL, Rodríguez-Couto S. Transformation pathway of Remazol Brilliant Blue R by immobilised laccase, Bioresource Technology, 101: 8509-8514, 2010.

doi: 10.1016/j.biortech.2010.06.074

Pedroza-Camacho LD, Lores-Acosta JC, Rojas-Enríquez JF, MateusMaldonado JF, Puentes CS, Ramírez-Rodríguez J, MendezCasallas FJ, Salcedo-Reyes JC, Díaz-Ariza LA, Lozano-Puentes HS, Pedroza-Rodríguez AM. Effect of Domestic Wastewater as Co-Substrate on Biological Stain Wastewater Treatment Using Fungal/Bacterial Consortia in Pilot Plant and Greenhouse Reuse, Journal of Water, Resource and Protection, 10: 369-393, 2018.

Pallerla S, Chambers R. Characterization of a Ca-Alginated-Inmovilized Trametes versicolor Bioreactor for Decolorization and AOX Reduction of Paper Mill Effluents, Bioresource Technology, 60:1-8, 1997.

doi: 10.1016/S0960-8524(96)00171-X

Puentes-Cárdenas IJ, Florido-Cuellar AE, Cardona-Bedoya JA, Bohórquez-Echeverry P, Campos-Pinilla MC, Pedroza-Rodríguez AM. Simultaneous decolorization and detoxification of black reactive 5 using $\mathrm{TiO}_{2}$ deposited over borosilicate glass, Universitas Scientiarum, 17: 53-63, 2012a

Puentes-Cárdenas IJ, Pedroza-Rodríguez AM, Navarrete-López M, Villegas-Garrido TL, Cristiani-Urbina E. Biosorption of trivalent chromium from aqueous solutions by Pleurotus ostreatus biomass, Environmental Engineering Management Journal, 11: 1741-1752, 2012b

Punzi M, Nilsson F, Anbalagan A, Svensson Britt-Marie, Jönsson K, Mattiasson Bo, Jonstrup M. Combined anaerobic-ozonation process for treatment of textile wastewater: Removal of acute toxicity and mutagenicity, Journal Hazardous Materials, 292: 52-60, 2015.

doi: 10.1016/j.jhazmat.2015.03.018

Qingxiang Y, Chunmao L, Huijun L, Yuhui L, Ning Y (2009). Degradation of synthetic reactive azo dyes and treatment of textile wastewater by a fungi consortium reactor, Biochemistry Engeneering Journal, 43: 225-230.

doi: 10.1016/j.bej.2008.10.002 
Rivera-Hoyos CM, Morales-Álvarez ED, Poutou-Piñales RA, Pedroza-Rodríguez AM, Rodríguez-Vázquez R, Delgado-Boada JM. Fungal laccases, Fungal Biology Review, 27: 67-82, 2013.

doi: 10.1016/j.fbr.2013.07.001

Rizzo L. Bioassays as a tool for evaluating advanced oxidation processes in water and wastewater treatment, Water Research, 45: 4311-4340, 2011.

doi: 10.1016/j.watres.2011.05.035

Russo M, Natale FDi, Prigione V, Tigini V, Marzocchella A, Varese GC. Adsorption of acid dyes on fungal biomass: equilibrium and kinetics characterization, Chemical Engineering Journal, 162: 537-545, 2010.

doi: 10.1016/j.cej.2010.05.058

Santoyo F, González A, Terron M, Ramírez L, Pisabarro A. Quantitative linkage mapping of lignin-degrading enzymatic activities in Pleurotus ostreatus, Enayme and Microbial Technology, 43: 137-143, 2018.

doi: 10.1016/j.enzmictec.2007.11.007

Satapanajaru T, Chompuchan C, Suntornchot P, Pengthamkeerati P. Enhancing decolorization of Reactive Black 5 and Reactive Red 198 during nano zerovalent iron treatment, Desalination, 266: 218-230, 2010.

doi: 10.1016/j.desal.2010.08.030

Sathian S, Rajasimman M, Rathnasabapathy CS, Karthikeyan C. Performance evaluation of SBR for the treatment of dyeing wastewater by simultaneous biological and adsorption processes, Journal of Water Process Engineering, 4: 82-90, 2014.

doi: 10.1016/j.jwpe.2014.09.004

Singh RL, Singh PK, Singh RP. Enzymatic decolorization and degradation of azo dyes- A review, International Biodeterioration Biodegradation, 104: 21-31, 2015.

doi: 10.1016/j.ibiod.2015.04.027

Sufian A, Hannan A, Rana M, Anibl M. Comparative study of fastness properties and color absorbance criteria of conventional and Avitera reactive Dyeing on cotton knit fabric, European Scientific Journal, 12(15): 353-364, 2016. 
Tinoco R, Pickard M.A, Vazquez-Duhalt R. Kinetic differences of purified laccases from six Pleurotus ostreatus strains, Letter Applied Microbiology, 32: 331-335, 2001.

doi: 10.1046/j.1472-765X.2001.00913.x

Trottier S, Blaise C, Kusui T, Johnson E. Acute toxicity Assessment of Aqueous Samples Using a Microplate-based Hydra attenuata Assay, Environmental Toxicology, 12: 265-271, 1997.

doi: 10.1002/(SICI)1098-2256(1997)12:3<265::AID-

TOX10>3.0.CO;2-9

Waghmode TR, Kurade MB, Khandare RV, Govindwar SP. A sequential aerobic/microaerophilic decolorization of sulfonated mono azo dye Golden Yellow HER by microbial consortium GG-BL, International deterioration Biodegradation, 65: 1024-1034, 2011.

doi: 10.1016/j.ibiod.2011.08.002

Yue Zhu Hua, Ru Jiang, Yu-Jiang Guan, Yong-Qian Fu, Ling Xiao, Guang-Ming Zeng. Effect of key operational factors on decolorization of methyl orange during $\mathrm{H}_{2} \mathrm{O}_{2}$ assisted CdS/ $\mathrm{TiO}_{2} /$ polymer nanocomposite thin films under simulated solar light Irradiation, Separation Purification Technology, 74(2): 187-194, 2010 .

doi: 10.1016/j.seppur.2010.06.004 


\section{Un novedoso tratamiento de aguas residuales de la industria textil usando co-cultivos ligninolíticos y fotocatálisis con $\mathrm{TiO}_{2}$}

Resumen. Las industrias textiles producen un efluente que, si es descargado, ejerce un impacto negativo en el ambiente. Así, es necesario diseñar e implementar soluciones novedosas para el tratamiento de estos desechos. Con el fin de decolorar, detoxificar y reutilizar aguas residuales producidas en la industria textil en ciclos de tinturado subsecuentes, se evaluó en laboratorio un tratamiento secuencial, consistente en un cultivo ligninolítico con los hongos Pleurotus ostreatus y Phanerochaete crbysosporium (tratamiento secundario) acoplado con fotocatálisis $\mathrm{TiO}_{2} / \mathrm{UV}$ (tratamiento terciario). Después de 48 horas de tratamiento secundario, se removió hasta un $80 \%$ del color del agua residual y las Demandas Química y Bioquímica de Oxígeno (DQO y $\mathrm{DBO}_{5}$ ) fueron reducidas en 92 y $76 \%$ respectivamente. Las actividades Lacasa y MnP (410 $\mathrm{U} \mathrm{L}^{-1}$ y $1428 \mathrm{U} \mathrm{L}^{-1}$, respectivamente) fueron centrales en la remoción de color y en la reducción de $\mathrm{DQO}$ y $\mathrm{DBO}_{5}$. Someter muestras de agua residual a 12 horas de tratamiento terciario resultó en una remoción de $86 \%$ de color, $73 \%$ de DQO y $86 \%$ de DBO. La aplicación de un tratamiento secuencial por $18 \mathrm{~h}$ incrementó su efectividad, lo cual resultó en 89 \% de remoción de color, además de 81 \% y 89 \% de remoción de $\mathrm{DQO}$ y $\mathrm{DBO}_{5}$ respectivamente. Con este tratamiento secuencial se observó una inactivación bacteriana del 55 \%. Las películas de $\mathrm{TiO}_{2}$ se reutilizaron continuamente durante 2 ciclos de tratamiento consecutivos sin reactivación térmica. Se alcanzaron porcentajes de remoción mayores al $50 \%$. Las pruebas de toxicidad aguda llevadas a cabo con agua residual cruda produjeron un nivel de letalidad del $100 \%$ a $50 \%$ en Hydra attenuata y una inhibición de crecimiento del $54 \%$ a $50 \%$ en Lactuca sativa. El agua residual tratada secuencialmente produjo una letalidad del $13 \%$ a $6.25 \%$ y una inhibición del $12 \%$ a $75 \%$ para $H$. attenuata y L. sativa, respectivamente. Finalmente, el agua residual tratada secuencialmente fue reutilizada en experimentos de tinturado en los que la cantidad de colorante absorbido fue de $0.86 \mathrm{mg} \mathrm{g}^{-1}$ por $\mathrm{g}$ de tela, lo cual es equivalente a $80 \%$ de adsorción.

Palabras clave: co-cultivo ligninolítico; fotocatálisis con $\mathrm{TiO}_{2}$; agua residual textil. 


\section{Um novo tratamento para águas residuais têxtis usando co-cultura ligninolítica e fotocatálise com $\mathrm{TiO}_{2}$}

Resumo. A indústria têxtil produz águas residuais que causam um impacto negativo ao meio ambiente quando são descartadas. Portanto, é necessário projetar e implementar novas soluções para seu tratamento. Um tratamento sequencial que consiste na co-cultura ligninolítica com os fungos Pleurotus ostreatus e Phanerochaete crbysosporium (tratamento secundário) acoplada à fotocatálise com $\mathrm{TiO}_{2} / \mathrm{UV}$ foi avaliado no laboratório para descolorir, desintoxicar e reutilizar água residual têxtil em ciclos subsequentes de tintura. Após 48 h de tratamento secundário, aproximadamente $80 \%$ da cor foi removida da água residual e sua demanda química e bioquímica de oxigênio (COD, e $\mathrm{BOD}_{5}$ ) foram diminuídas em $92 \%$ e $76 \%$, respectivamente. A atividade de Laccase e $\mathrm{MnP}$ foram centrais na remoção da cor e diminuição de COD e BOD mostrando valores de atividade de $410 \mathrm{U} \mathrm{L}^{-1}$ e $1428 \mathrm{U} \mathrm{L}^{-1}$, respectivamente. Submeter as amostras de água residual a $12 \mathrm{~h}$ de tratamento terciário levou a uma remoção de $86 \%$ da cor e uma diminuição de $73 \%$ e $86 \%$ de $\mathrm{COD}$ e $\mathrm{BOD}_{5}$ respectivamente. A aplicação do tratamento sequencial por $18 \mathrm{~h}$ melhorou a efetividade do tratamento de águas residuais, resultando em $89 \%$ de remoção de cor e uma diminuição de $81 \%$ e $89 \%$ de $\mathrm{COD}$ e $\mathrm{BOD}_{5}$, respectivamente. Com este tratamento sequencial, observamos uma inativação bacteriana de $55 \%$. As películas de $\mathrm{TiO}_{2}$ foram reutilizadas continuamente durante dois tratamentos consecutivos sem reativação térmica. Atingimos porcentagens de remoção acima de $50 \%$. Os testes de toxicidade aguda feitos em água residual sem tratar causaram níveis de letalidades de $100 \%$ a $50 \%$ em Hydra attenuata e uma inibição do crescimento de $54 \%$ a $50 \%$ em Lactuca sativa. Enquanto água residual tratada sequencialmente causou uma letalidade de $13 \%$ a $6.25 \%$ e uma inibição de $12 \%$ a $75 \%$ para $H$. attenuata e L. sativa, respectivamente. Finalmente, a água residual tratada sequencialmente foi reutilizada em experimentos de tintura nos quais absorveu $0.86 \mathrm{mg}$ $\mathrm{g}^{-1}$ por $\mathrm{g}$ de tecido, o que é equivalente a uma absorção de $80 \%$.

Palavras-chave: co-cultura ligninolítica; fotocatálise com $\mathrm{TiO}_{2}$; água residual têxtil. 

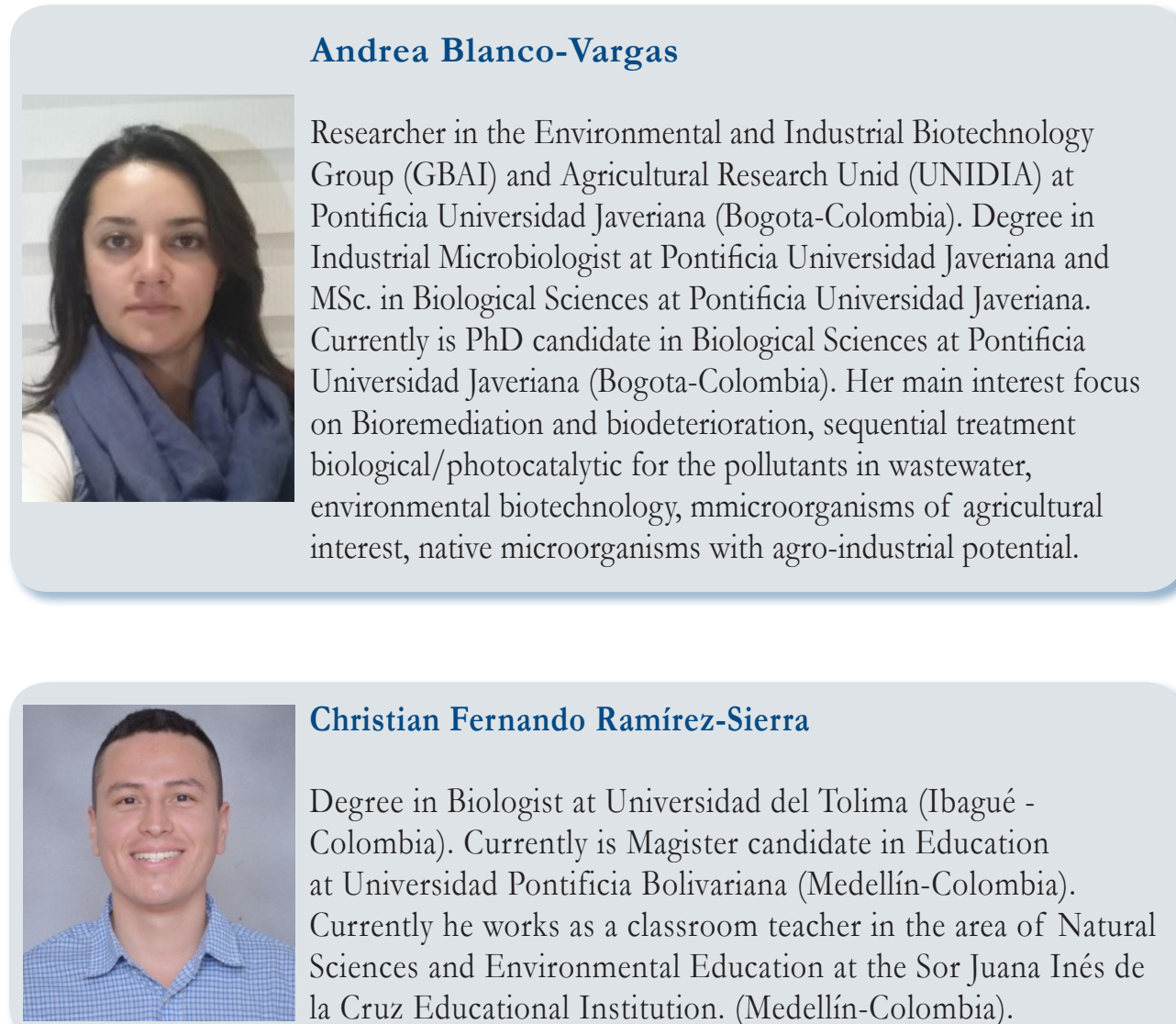

\section{Christian Fernando Ramírez-Sierra}

Degree in Biologist at Universidad del Tolima (Ibagué Colombia). Currently is Magister candidate in Education at Universidad Pontificia Bolivariana (Medellín-Colombia). Currently he works as a classroom teacher in the area of Natural Sciences and Environmental Education at the Sor Juana Inés de la Cruz Educational Institution. (Medellín-Colombia).

\section{Marcela Duarte-Castañeda}

Degree in Industrial Microbiologist at Pontificia Universidad Javeriana (Bogotá-Colombia). Her main interest focus on Environmetal Microbiology, Microbiological quality control in Waters, Toxicity tests in wastewater, drinking water, surface water, sludge, composting, bioinduces and biological inoculants. She has experience in ISO 17025: 2005, ISO 9001: 2015 and OSHAS 18000: 2007 ; intermediate management of office automation and telematic tools.

\section{Milena Beltrán-Villarraga}

Degree in Industrial Microbiologist at Pontificia Universidad Javeriana (BogotáColombia). She worked as a researcher in the Department of Microbiology of the University with experience in the area of Microbiological Quality Indicators in environmental matrices: water, sludge and vegetables. She worked on projects to evaluate indicators of bacteriological and parasitological quality in surface water, sludge resulting from chemical and primary treatment in Wastewater treatment plants, vegetation irrigated with treated water and treated with biosolids. 


\section{Luz Karime Medina}

Degree in Industrial Microbiologist at Pontificia Universiadad Javeriana (Bogotá-Colombia). M.Sc. in Biological Sciences at Pontificia Universidad Javeriana (Bogotá D.C.-Colombia). She is currently a Ph.D. student at the Biological Sciences School at the Georgia Institute of Technology, Atlanta, USA. Her research interests are based on Environmental Microbiology, Molecular Biology, Metagenomics and Computational Genomics.

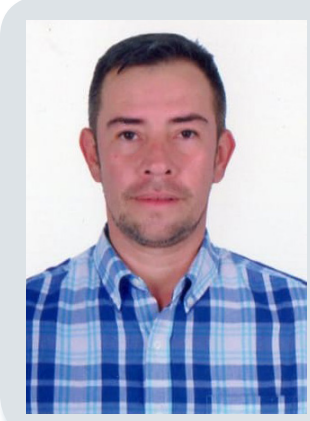

\section{Alex-Enrique Florido-Cuellar}

Bachelor in Mathematical and Physics at Universidad del Tolima (Ibagué-Colombia). MS. in Advanced Technology at Centro de Investigación en Ciencia Aplicada y Tecnología Avanzada- IPN. CICATA. (México D.F.). Ph.D. in Advaced Technology at Centro de Investigación en Ciencia Aplicada y Tecnología Avanzada- IPN CICATA" (México D.F.). Professor Universidad Nacional Abierta y a distancia UNAD.

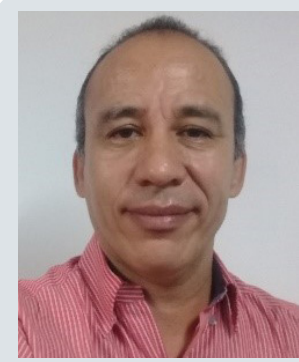

\section{Jairo Armando Cardona-Bedoya}

Bachelor in Mathematical and Physics at Universidad del Tolima. (Ibagué-Colombia). MS. In Physics at "Centro de Investigaciones y estudios Avanzados CINVESTAV" (México D.F.). Ph.D. in Physic at "Centro de Investigaciones y estudios Avanzados CINVESTAV" (México D.F.). Professor Universidad del Tolima

\section{Claudia Campos-Pinilla}

Bacteriologist, Clinical Microbiology Specialist, Master of Science, Master in Water Technology. PhD in Biology and Diploma in Epidemiology and Public Health. Titular Professor Pontificia Universidad Javeriana and Coordinator of the Water and Sludge Quality Laboratory. 30 years of experience in microbiological and toxicological water quality assessment and environmental and health risk.

\section{Aura Marina Pedroza-Rodríguez}

Professor of Microbiology Department. COLCIENCIAS Senior researcher. Degree in Bacteriology and M.Sc. in Microbiology at "Pontificia Universidad Javeriana" (Colombia), Ph.D. in Biological Sciences at "Centro de Investigaciones y estudios Avanzados CINVESTAV" (México D.F.). Currently researcher at Environmental and Industrial Biotechnology Group (GBAI). One of her main research interests focus on unconventional biological systems and advanced oxidation processes for the removal of pollutants in waste water. 